\title{
Flight-based chemical characterization of biomass burning aerosols within two prescribed burn smoke plumes
}

\author{
K. A. Pratt ${ }^{1,2,{ }^{*}}$, S. M. Murphy ${ }^{3,4}$, R. Subramanian ${ }^{5}$, P. J. DeMott ${ }^{6}$, G. L. Kok ${ }^{5}$, T. Campos $^{7}$, D. C. $\operatorname{Rogers}^{7}$, \\ A. J. Prenni ${ }^{6}$, A. J. Heymsfield ${ }^{7}$, J. H. Seinfeld ${ }^{3}$, and K. A. Prather ${ }^{1,8}$ \\ ${ }^{1}$ Department of Chemistry and Biochemistry, University of California, San Diego, La Jolla, CA, USA \\ ${ }^{2}$ Atmospheric Science and Global Change Division, Pacific Northwest National Laboratory, Richland, WA, USA \\ ${ }^{3}$ Division of Chemistry and Chemical Engineering, California Institute of Technology, Pasadena, CA, USA \\ ${ }^{4}$ Chemical Sciences Division, Earth System Research Laboratory, National Oceanic \& Atmospheric Administration, Boulder, \\ CO, USA \\ ${ }^{5}$ Droplet Measurement Technologies, Boulder, CO, USA \\ ${ }^{6}$ Department of Atmospheric Science, Colorado State University, Fort Collins, CO, USA \\ ${ }^{7}$ National Center for Atmospheric Research, Boulder, CO, USA \\ ${ }^{8}$ Scripps Institution of Oceanography, University of California, San Diego, La Jolla, CA, USA \\ * now at: Department of Chemistry, Purdue University, West Lafayette, IN, USA
}

Received: 14 April 2011 - Published in Atmos. Chem. Phys. Discuss.: 22 June 2011

Revised: 19 November 2011 - Accepted: 2 December 2011 - Published: 15 December 2011

\begin{abstract}
Biomass burning represents a major global source of aerosols impacting direct radiative forcing and cloud properties. Thus, the goal of a number of current studies involves developing a better understanding of how the chemical composition and mixing state of biomass burning aerosols evolve during atmospheric aging processes. During the Ice in Clouds Experiment-Layer Clouds (ICE-L) in the fall of 2007, smoke plumes from two small Wyoming Bureau of Land Management prescribed burns were measured by online aerosol instrumentation aboard a C-130 aircraft, providing a detailed chemical characterization of the particles. After $\sim 2-4$ min of aging, submicron smoke particles, produced primarily from sagebrush combustion, consisted predominantly of organics by mass, but were comprised primarily of internal mixtures of organic carbon, elemental carbon, potassium chloride, and potassium sulfate. Significantly, the fresh biomass burning particles contained minor mass fractions of nitrate and sulfate, suggesting that hygroscopic material is incorporated very near or at the point of emission. The mass fractions of ammonium, sulfate, and nitrate increased with aging up to $\sim 81-88 \mathrm{~min}$ and resulted in acidic particles. Decreasing black carbon mass concentrations occurred due to
\end{abstract}

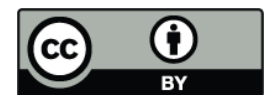

Correspondence to: K. A. Prather (kprather@ucsd.edu) dilution of the plume. Increases in the fraction of oxygenated organic carbon and the presence of dicarboxylic acids, in particular, were observed with aging. Cloud condensation nuclei measurements suggested all particles $>100 \mathrm{~nm}$ were active at $0.5 \%$ water supersaturation in the smoke plumes, confirming the relatively high hygroscopicity of the freshly emitted particles. For immersion/condensation freezing, ice nuclei measurements at $-32{ }^{\circ} \mathrm{C}$ suggested activation of $\sim 0.03-0.07 \%$ of the particles with diameters greater than $500 \mathrm{~nm}$.

\section{Introduction}

Biomass burning emissions produce a considerable amount of greenhouse gases and are estimated to contribute $~ 34$ $38 \%$ of global carbonaceous aerosol (Forster et al., 2007). Biomass burning aerosols exert a significant, but uncertain, direct radiative forcing of $+0.03[ \pm 0.12] \mathrm{W} \mathrm{m}^{-2}$, which is strongly influenced by aerosol overlying clouds (Forster et al., 2007; Chand et al., 2009). Wildfires also serve as large sources of cloud condensation nuclei $(\mathrm{CCN})$ with a wide range of hygroscopicities (Petters et al., 2009a; Carrico et al., 2010) and can also be a source of heterogeneous ice nuclei (IN) with number concentrations suggested to be of regional importance (Pueschel and Langer, 1973; Petters et al., 2009b; Twohy et al., 2010). Biomass burning aerosols have

Published by Copernicus Publications on behalf of the European Geosciences Union. 
been identified as having a significant anthropogenic component, and emissions are expected to increase further by a warming climate and land-use changes (Westerling et al., 2006; Forster et al., 2007; Spracklen et al., 2009). In the western United States, biomass burning contributes 50\% of the annual average total carbonaceous aerosol mass concentrations and $\sim 30 \%$ of total fine aerosol mass concentrations (Park et al., 2007). Moreover, in the United States, large wildfire activity has increased in recent years with higher large-wildfire frequency, longer wildfire durations, and longer wildfire seasons, particularly in the mid-elevation northern Rocky Mountains (Westerling et al., 2006). Recent modeling by Spracklen et al. (2009) estimates an increase of $54 \%$ in the annual mean area burned in the western United States from 2000 to 2050, corresponding to increases in summertime organic carbon (OC) and elemental carbon (EC) aerosol concentrations in the western United States of $30 \%$ and $19 \%$, respectively.

Numerous studies have investigated the physical and chemical characteristics of biomass burning aerosols. In general, fresh dry smoke particles, primarily in the submicron size range, have been found to consist of $\sim 80 \%$ OC, $\sim 5-9 \%$ black carbon (BC), and $\sim 12-15 \%$ trace inorganics, such as potassium, sulfate, chloride, and nitrate (Reid et al., 2005b). These individual particles are usually internally mixed with a core of black carbon and alkali earth compounds coated with organics (Reid et al., 2005b). Different fuels and combustion conditions produce particles of varying chemical composition, with potassium and soot enhanced in flaming combustion, for example (Reid et al., 2005b; Cahill et al., 2008). Following emission, particle growth is rapid with aged smoke becoming enriched in sulfate, nitrate, organic acids and semivolatile organic species (Gao et al., 2003; Reid et al., 2005b). Most chemical characterization studies have utilized filterbased thermal desorption methods to quantify $\mathrm{OC}$ and $\mathrm{BC}$; however, these methods can suffer from sampling artifacts and uncertainties in evolution temperatures. Thus, quantification of organic carbon and black carbon from biomass burning was identified in a review by Reid et al. (2005b) as the greatest need in smoke particle chemistry research. A secondary recommendation by Reid et al. (2005b) was to investigate further the aging of smoke particles immediately following emission with high time resolution to bridge the gap between fresh and aged biomass burning aerosols, the physical and chemical properties of which impacts optical properties and cloud-forming potentials.

Most airborne plume studies, including recent measurements (Capes et al., 2008; Yokelson et al., 2009), have focused on large fires. Herein we examine two relatively small prescribed burns at low ambient temperatures. Prescribed fires provide the opportunity for a detailed characterization of both burn conditions and consequent emissions in a real-world setting, combining the advantages of studying wildfires and laboratory fires. In addition, prescribed fires may serve as a means to reduce $\mathrm{CO}_{2}$ fire emissions in the western United States (Wiedinmyer and Hurteau, 2010). During the Ice in Clouds Experiment-Layer Clouds (ICEL) in November 2007, the smoke plumes of two prescribed burns were intercepted during flights of the National Center for Atmospheric Research/ National Science Foundation (NSF/NCAR) C-130 aircraft. The young smoke plumes were investigated in detail utilizing a unique suite of real-time aerosol instrumentation, measuring single-particle chemical composition, non-refractory aerosol mass concentrations, and black carbon mass concentrations. Concurrent measurements of CCN and IN were also obtained and provide a basis for discussing aerosol cloud activation properties.

\section{Experimental}

\subsection{Overview}

Measurements within two Wyoming Bureau of Land Management (BLM) prescribed burn smoke plumes were made aboard the NSF/NCAR C-130 aircraft during ICE-L research flights \#1 (RF01) and \#3 (RF03) in November 2007. An overview of the prescribed burns and ground conditions, provided by the Wyoming BLM, is detailed in Table 1, presenting date, latitude, longitude, elevation, burn time, ambient temperature, relative humidity, wind speed, burn area, fuel types, and live fuel moisture. There was no surface snow cover in the vicinity of these burns. The flight procedure was as follows: when a smoke plume was sighted, the C-130 crossed the plume centerline at a downwind location and then turned into the wind, following the smoke toward its source. C-130 aircraft sampling time periods and altitudes are shown in Table 2. Background concentrations were measured immediately before and after sampling of the plume (generally $\sim 30 \mathrm{~s}$ to $2.5 \mathrm{~min}$ ). Differing sampling time delays were accounted for to synchronize all data shown herein. Latitude, longitude, and altitude were sampled at $10 \mathrm{~Hz}$ by GPS and averaged to $1 \mathrm{~Hz}$.

Carbon monoxide (CO) was measured at $1 \mathrm{~Hz}$ using a vacuum ultraviolet resonance fluorescence instrument (AeroLaser AL5002). Ozone $\left(\mathrm{O}_{3}\right)$ was measured at $1 \mathrm{~Hz}$ using an "inverse" NO chemiluminescence instrument. Relative humidity was measured using a Buck Research multistage hygrometer $( \pm 5 \%$ uncertainty). An Ultra High Sensitivity Aerosol Spectrometer (UHSAS, Particle Metrics Inc., Boulder, $\mathrm{CO}$ ) provided size-resolved aerosol number concentrations $(0.1-1.0 \mu \mathrm{m}$ in diameter). Calibration of the UHSAS was performed using standard polystyrene latex spheres, which may underestimate the size of smoke particles, which have lower refractive indices (Reid et al., 2005a); spherical particles were assumed to obtain sizeresolved volume distributions, consistent with previous wildfire studies (e.g., Yokelson et al., 2009). Total condensation nuclei $(\mathrm{CN})$ concentrations were measured using a condensation particle counter (CPC, TSI Model 3760), 
Table 1. Prescribed burn and ground conditions, provided by the Wyoming BLM, for the RF01 and RF03 smoke plumes.

\begin{tabular}{lll}
\hline & RF01 Plume & RF03 Plume \\
\hline Date & 7 November 2007 & 16 November 2007 \\
Latitude & $41^{\circ} 38^{\prime} 06^{\prime \prime} \mathrm{N}$ & $42^{\circ} 31^{\prime} 04^{\prime \prime} \mathrm{N}$ \\
Longitude & $107^{\circ} 23^{\prime} 10^{\prime \prime} \mathrm{W}$ & $106^{\circ} 21^{\prime} 59^{\prime \prime} \mathrm{W}$ \\
Elevation & $2499-2560 \mathrm{~m}$ & $2267-2359 \mathrm{~m}$ \\
Burn Time & $20: 00-00: 00 \mathrm{UTC}$ & $18: 45-22: 15 \mathrm{UTC}$ \\
Ambient Temperature & $10^{\circ} \mathrm{C}$ & $8-13^{\circ} \mathrm{C}$ \\
Relative Humidity & $26 \%$ & $29-36 \%$ \\
Wind Speed & $7-8 \mathrm{~m} \mathrm{~s}^{-1}$, gusts to $12 \mathrm{~m} \mathrm{~s}^{-1}$ & $3-6 \mathrm{~m} \mathrm{~s}^{-1}$, gusts to $8 \mathrm{~m} \mathrm{~s}^{-1}$ \\
Burn Area & $0.8-0.9 \mathrm{~km}^{2}$ & $0.3 \mathrm{~km}^{2}$ \\
Fuel Type (s) & $\sim 90 \% \mathrm{mountain}^{2}$ big sagebrush & $\sim 75 \%$ mountain big sagebrush (live), \\
& $($ live $), 10 \%$ aspen (live) & $\sim 20 \%$ mountain mahogany (dormant), \\
& & $\sim 5 \%$ Rocky Mountain juniper \\
Live Fuel Moisture & $\sim 82 \%$ & $\sim 70 \%$ \\
\hline
\end{tabular}

Table 2. C-130 aircraft sampling time periods and altitudes for the RF01 and RF03 smoke plumes, as well as the estimated aerosol age, based on $\mathrm{C}-130$ location and wind speed data. For carbon monoxide $(\mathrm{CO})$, ozone $\left(\mathrm{O}_{3}\right)$, total condensation nuclei $(\mathrm{CN})$, particles $>0.1 \mu \mathrm{m}$ $\left(\mathrm{N}_{>0.1}\right)$, and particles $>0.5 \mu \mathrm{m}\left(\mathrm{N}_{>0.5}\right)$, average background concentrations (with standard deviations in parentheses) are shown along with the range of concentrations observed in the plume. Average horizontal and vertical wind speed, ambient temperature, and relative humidity, measured aboard the C-130 aircraft are shown with standard deviations.

\begin{tabular}{|c|c|c|}
\hline & RF01 Plume & RF03 Plume \\
\hline Plume Sampling Time Period & 21:46:17-21:50:10 UTC & 22:08:24-22:26:35 UTC \\
\hline Aircraft Altitude (AGL) & $1034-1807 \mathrm{~m}$ & $183-3451 \mathrm{~m}$ \\
\hline Sampled Aerosol Age & $\sim 17-30 \mathrm{~min}$ & $\sim 2 \min -\sim 2 \mathrm{~h}$ \\
\hline Average Background [CO] & 81 (1) ppbv & $92.6(0.9) \mathrm{ppbv}$ \\
\hline Plume $[\mathrm{CO}]$ & $80-184 \mathrm{ppbv}$ & $87-311 \mathrm{ppbv}$ \\
\hline Average Background $\left[\mathrm{O}_{3}\right]$ & 112 (4) ppbv & $102(4) \mathrm{ppbv}$ \\
\hline Average Plume $\left[\mathrm{O}_{3}\right]$ & 112 (4) ppbv & $93(7) \mathrm{ppbv}$ \\
\hline Average Background [CN] & $211(12) \mathrm{cm}^{-3}$ & $865(570) \mathrm{cm}^{-3}$ \\
\hline Plume $[\mathrm{CN}]$ & $193-9591 \mathrm{~cm}^{-3}$ & $203-66061 \mathrm{~cm}^{-3}$ \\
\hline Average Background $\left[\mathrm{N}_{>0.1}\right]$ & $56(19) \mathrm{cm}^{-3}$ & $183(55) \mathrm{cm}^{-3}$ \\
\hline Plume $\left[\mathrm{N}_{>0.1}\right]$ & $33-4949 \mathrm{~cm}^{-3}$ & $17-12698 \mathrm{~cm}^{-3}$ \\
\hline Average Background $\left[\mathrm{N}_{>0.5}\right]$ & $0.3(0.9) \mathrm{cm}^{-3}$ & $3(3) \mathrm{cm}^{-3}$ \\
\hline Plume $\left[\mathrm{N}_{>0.5}\right]$ & $0-15 \mathrm{~cm}^{-3}$ & $0-215 \mathrm{~cm}^{-3}$ \\
\hline Wind Speed, Horizontal & $15(1) \mathrm{m} \mathrm{s}^{-1}$ & $17(2) \mathrm{m} \mathrm{s}^{-1}$ \\
\hline Wind Speed, Vertical & $0.1(1.1) \mathrm{m} \mathrm{s}^{-1}$ & $-0.3(1.0) \mathrm{m} \mathrm{s}^{-1}$ \\
\hline Ambient Temperature & $0.2(1.5)^{\circ} \mathrm{C}$ & $1.1(4.2)^{\circ} \mathrm{C}$ \\
\hline Relative Humidity & $21(6) \%$ & $46(4) \%$ \\
\hline
\end{tabular}

detecting particles $>\sim 13 \mathrm{~nm}$ in diameter and corrected for coincidence. Aerosol chemical composition was measured using several real-time techniques, described below.

\subsection{Aircraft aerosol time-of-flight mass spectrometer (A-ATOFMS)}

In-situ measurements of the size-resolved chemical composition of individual submicron particles were made using the recently developed aircraft aerosol time-of-flight mass spectrometer (A-ATOFMS) (Pratt et al., 2009). The A-ATOFMS measures, in real-time, the vacuum aerodynamic diameter $\left(d_{\mathrm{va}}\right)$ and dual-polarity mass spectra of individual particles from $\sim 70-1200 \mathrm{~nm}\left(d_{\mathrm{va}}\right)$. Following a ${ }^{210}$ Po neutralizer and pressure-controlled inlet (Bahreini et al., 2008), particles are focused in an aerodynamic lens system. Particles are optically detected by two continuous wave $532 \mathrm{~nm}$ lasers spaced $6.0 \mathrm{~cm}$ apart, providing particle velocity and, thus, $d_{\text {va }}$. Polystyrene latex spheres of known physical diameter from 95-1500 $\mathrm{nm}$ were used for the particle size calibration. During ICE-L, particles were desorbed and ionized using $266 \mathrm{~nm}$ radiation from a Q-switched Nd:YAG laser operating at $\sim 0.4-0.6 \mathrm{~mJ}$. Positive and negative ions 
resulting from individual particles are detected within the time-of-flight mass spectrometer. For the analysis discussed herein, 162 and 1212 individual particles were chemically analyzed during RF01 and RF03 plume sampling, respectively. Standard errors of particle type number percentages were calculated assuming Poisson statistics. Mass spectral peak identifications correspond to the most probable ions for a given $m / z$ ratio based on previous lab and field studies; the peak area of a specific $m / z$ is related the amount of a specific species on each particle (Bhave et al., 2002).

\subsection{Compact time-of-flight aerosol mass spectrometer (C-ToF-AMS)}

The Aerodyne compact time-of-flight aerosol mass spectrometer (C-ToF-AMS) ()(Drewnick et al., 2005) measured the mass concentrations of non-refractory species (organics, sulfate, nitrate, ammonium, and a fraction of chloride) in real-time. Particles of $d_{\mathrm{va}} \sim 50-800 \mathrm{~nm}$ are focused by an aerodynamic lens system, sent through a $3.5 \%$ chopper, and then impacted onto a tungsten vaporizer operated at $550-560^{\circ} \mathrm{C}$. The chopper can be operated in three modes to gather either background mass spectra, ensemble average mass spectra over all particle sizes, or size-resolved mass spectra. Measurements of chloride and other semirefractory species are reported herein, but concentrations of these species are significantly underestimated by the C-ToFAMS because they are not efficiently volatilized at the vaporizer temperature $\left(550-560^{\circ} \mathrm{C}\right)$ used. Once vaporized, molecules undergo electron impact ionization and are extracted at a rate of $\sim 53 \mathrm{kHz}$ into a time-of-flight mass analyzer. For this airborne deployment, the C-ToF-AMS was fitted with a pressure-controlled inlet (Bahreini et al., 2008) to prevent fluctuations in particle sizing and focusing with ambient pressure.

Detection limits were calculated as the standard deviation of the noise when measuring filtered air $(15 \mathrm{~s}$ averaging): organics $\left(0.08 \mu \mathrm{g} \mathrm{m}^{-3}\right)$, sulfate $\left(0.02 \mu \mathrm{g} \mathrm{m}^{-3}\right)$, nitrate $\left(0.01 \mu \mathrm{g} \mathrm{m}^{-3}\right)$, ammonium $\left(0.07 \mu \mathrm{g} \mathrm{m}^{-3}\right)$, and chloride $\left(0.01 \mu \mathrm{g} \mathrm{m}^{-3}\right)$. In practice, detection is often limited by counting statistics at low aerosol loadings. Considering an average smoke particle density of $\sim 1.2 \mathrm{~g} \mathrm{~cm}^{-3}$ (Reid et al., 2005b), comparison of the C-ToF-AMS size-resolved mass distribution with the UHSAS volume distribution yields an estimated collection efficiency (CE) (Huffman et al., 2005) of $\sim 0.28-0.55$, similar to a previously derived CE of 0.34 for ambient biomass burning measurements (Capes et al., 2008). Changes in the estimated CE through the plumes suggests changes in particle phase (Matthew et al., 2008), density, and/or the fraction of refractory material; herein, a CE of 0.4 is utilized with reported uncertainties reflecting variability in $\mathrm{CE}$, as well as the mass measurement. In addition, due to possible interference from the abundance of organics (and because nitrate mass loadings were very low), reported nitrate mass concentrations may be a factor of 2-3 high; this is reflected in the reported uncertainty for the nitrate and organic mass concentrations. Oxygen/carbon $(\mathrm{O} / \mathrm{C})$ ratios were calculated from unit resolution mass spectra following the estimation method developed, using a high resolution ToFAMS, by Aiken et al. (2008):

$\mathrm{O} / \mathrm{C}=(0.0382 \pm 0.0005)(x)+(0.0794 \pm 0.0070)$

where $x$ is the percentage of organic aerosol mass from $m / z 44\left(\mathrm{CO}_{2}^{+}\right)$, which was corrected based on background gas-phase $\mathrm{CO}_{2}$ concentration. Given that $\mathrm{CO}_{2}$ concentrations are enhanced within smoke plumes, this may lead to an overestimation of the organic aerosol mass and $\mathrm{O} / \mathrm{C}$ ratio.

\subsection{Single particle soot photometer (SP2)}

Particles containing black carbon (BC) were measured by a single particle soot photometer (SP2, Droplet Measurement Technologies, Boulder, CO), a laser-induced incandescence instrument (Schwarz et al., 2006; Baumgardner et al., 2008). During ICE-L, the SP2 measured BC mass in the range of $0.5-10.5$ fg-BC $(0.08-0.22 \mu \mathrm{m}$ BC mass equivalent diameter); $\mathrm{BC}$ particles greater than $\sim 10.5 \mathrm{fg}$ saturate the incandescence detector. Due to the limited $\mathrm{BC}$ mass range, scaling factors for the below- and above-detection limit BC masses were generated and applied to estimate total $\mathrm{BC}$ mass. The estimated uncertainty in BC mass is $\pm 20 \%$ (Baumgardner et al., 2007); however, variations in $B C$ mass were observed to be greater and thus are noted as the variability in BC mass fraction. The separation between the scattering and incandescent peaks, termed the incandescent lag, was utilized to examine the BC coating thickness where "thinly-coated" BC particles have short incandescent lags $(<2 \mu \mathrm{s})$ and "thicklycoated" BC particles have longer incandescent lags ( $>2 \mu \mathrm{s})$ (Moteki and Kondo, 2007; Moteki et al., 2007; Subramanian et al., 2010). Since the lower limit of the scattering detector is $\sim 200 \mathrm{~nm}$, the reported number fraction of thickly-coated BC particles is likely a lower limit (Subramanian et al., 2010).

\subsection{Cloud activation measurements}

$\mathrm{CCN}$ number concentration measurements were made using a stream-wise thermal gradient CCN counter (Droplet Measurement Technologies, Boulder, CO), described previously in detail by Roberts and Nenes (2005). During plume measurements, water supersaturation was held constant at $0.5 \%$. $\mathrm{CCN}$ concentrations were corrected for ambient temperature and pressure. The number concentrations of ice-nucleating aerosol particles were measured in real-time using a continuous flow diffusion chamber (CFDC) (Rogers et al., 2001; Eidhammer et al., 2010). By simulating cloud conditions at relative humidities exceeding $102 \%$ (with respect to water), the CFDC emphasized condensation/immersion freezing nucleation. Use of an impactor limited sampling to primarily submicron particles $(<\sim 1.5 \mu \mathrm{m}$ in aerodynamic diameter) prior 
to CFDC processing in order to distinguish ice crystals nucleated in the CFDC from non-activated aerosol particles using optical methods.

\section{Results and Discussion}

\subsection{Prescribed burn and plume conditions}

In November 2007, two Wyoming BLM prescribed burn smoke plumes were characterized by instruments on the NSF/NCAR C-130 aircraft. Ground-based details of the burns are noted in Table 1. The fuels of the RF01 and RF03 burns were dominated by live mountain big sagebrush (Artemisia tridentate ssp. vaseyana) $(\sim 90 \%$ and $\sim 75 \%$, respectively) with fuel moistures estimated at $\sim 82 \%$ and $\sim 70 \%$, respectively. From ground-based observations, the RF01 burn was characterized as a flaming fire with $3-5 \mathrm{~m}$ flame lengths and a burn rate of $0.8-1.0 \mathrm{~km} \mathrm{~h}^{-1}$. Although the RF03 burn was also characterized as a flaming fire, a smoldering component was observed to be associated with the dormant mountain mahogany (Cercocarpus). These prescribed burns were relatively small with burn areas of $\sim 0.8$ $0.9 \mathrm{~km}^{2}$ and $0.3 \mathrm{~km}^{2}$, respectively, too small for detection by satellite imagery. Photographs of the RF03 prescribed burn location prior to the burn, as well as the smoke plume as viewed from the C-130 aircraft, are shown in Fig. 1.

\subsubsection{Smoke plume RF01}

The C-130 aircraft intersected the RF01 smoke plume for a period of $\sim 4$ min (aircraft time) with sampling occurring at $1.0-1.8 \mathrm{~km}$ above ground level, as shown in Table 2. Based on average wind speeds, burn location, and flight path, the transport time of the smoke plume particles sampled was $\sim 17-30 \mathrm{~min}$ from the burn source to the sampling points. CO concentrations within the plume (80-184 ppbv) were up to 2.3 times greater than those measured in the nearby background air $(81 \pm 1 \mathrm{ppbv}) . \mathrm{O}_{3}$ concentrations within the plume were similar to background conditions; however, longer plume aging may be required for the photochemical production of $\mathrm{O}_{3}$ (Goode et al., 2000; Yokelson et al., 2009). Total $\mathrm{CN}$ number concentrations within the smoke plume (193-9591 $\mathrm{cm}^{-3}$ ) were up to $\sim 45$ times greater than background conditions $\left(211 \pm 12 \mathrm{~cm}^{-3}\right)$. Similarly, number concentrations of particles with $0.11-0.1 \mu \mathrm{m}$ diameters $\left(N_{>0.1}\right)\left(33-4949 \mathrm{~cm}^{-3}\right)$ were elevated by up to a factor of $\sim 88$ compared to background concentrations $\left(56 \pm 19 \mathrm{~cm}^{-3}\right)$. $\Delta \mathrm{CN} / \Delta \mathrm{CO}$ ratios, calculated by dividing excess $\mathrm{CN}$ ([CN] $\left.-\left[\mathrm{CN}_{\text {background }}\right]\right)$ by excess $\mathrm{CO}\left([\mathrm{CO}]-\left[\mathrm{CO}_{\text {background }}\right]\right)$, ranged from $2-3261 \mathrm{~cm}^{-3} \mathrm{ppbv}^{-1}$. Similarly, $\Delta \mathrm{N}_{>0.1} / \Delta \mathrm{CO}$ ratios were $0.6-347 \mathrm{~cm}^{-3} \mathrm{ppbv}^{-1}$, which span a larger range and a higher values than previous measurements of fresh Amazonian smoke $\left(<76 \mathrm{~cm}^{-3} \mathrm{ppb}^{-1}\right)$ summarized by Guyon et al. (2005). For this small section of the plume,

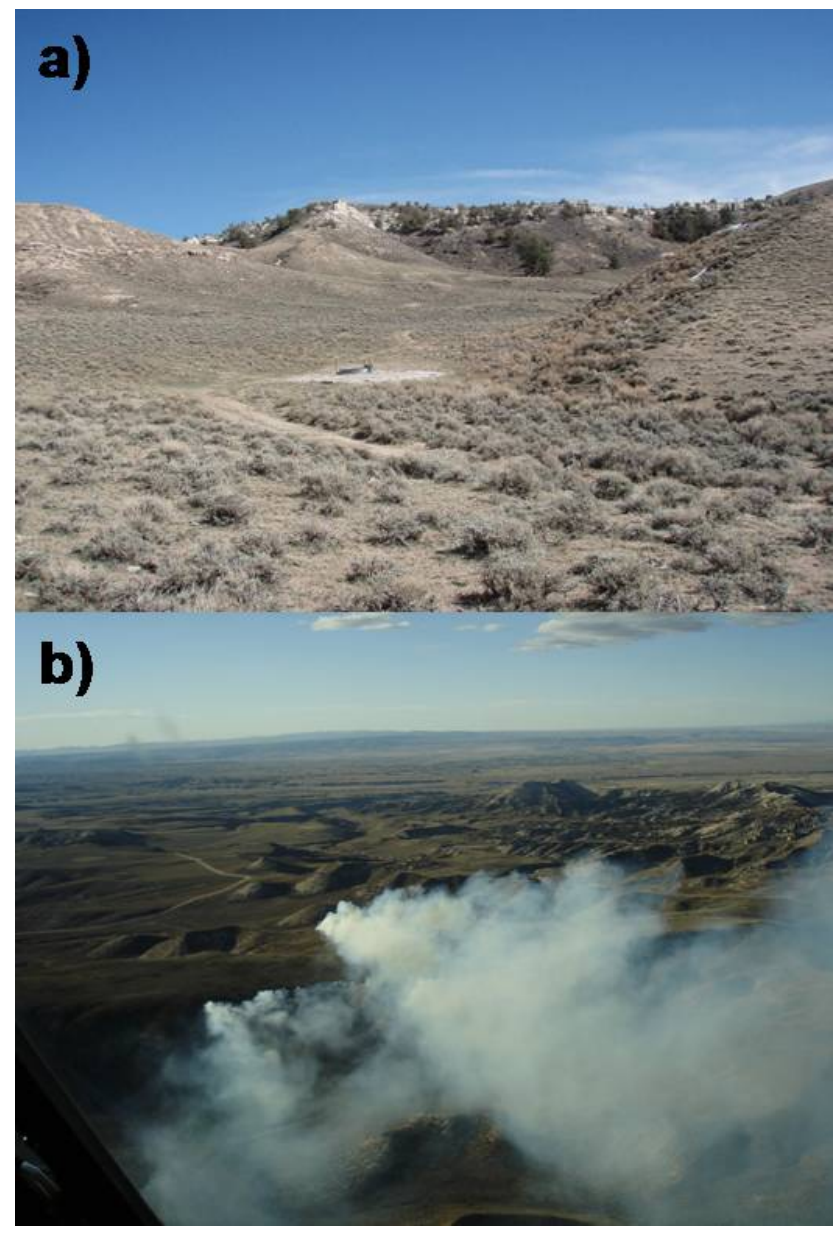

Fig. 1. Photographs of the RF03 prescribed burn: (a) location prior to the burn (courtesy of Kristi Bulock) and (b) smoke plume as viewed from the C-130 aircraft (courtesy of David Rogers).

$\Delta \mathrm{CN}$ and $\Delta \mathrm{N}_{>0.1}$ were not highly correlated with $\Delta \mathrm{CO}$ $\left(R^{2}=0.29\right.$ and 0.38 , respectively).

\subsubsection{Smoke plume RF03}

The RF03 smoke plume was sampled for $\sim 18$ min (aircraft time) at $0.2-3.5 \mathrm{~km}$ above ground level, as described in Table 2. Four time periods were selected to focus analyses during this long time interval. Period 1 corresponds to the sampling closest to the burn, where smoke particle age was calculated to be $\sim 2-4 \mathrm{~min}$. The furthest sampling point from the burn source corresponded to a smoke age of $\sim 117 \mathrm{~min}$. This long span allows an examination of transformations as the smoke particles aged.

The temporal profile of size-resolved particle number concentrations with associated $\mathrm{CO}$ and $\mathrm{O}_{3}$ concentrations is shown in Fig. 2. Large variations in the measurements reflect the meandering of this small plume and the effects of turbulence mixing with the relatively clean background. Since CO data are not available for sampling closest to the burn source, 
Table 3. Submicron aerosol mass fractions, shown as percentages with uncertainty ranges, considering black carbon, measured by the SP2, as well as non-refractory organics, sulfate, nitrate, ammonium, and chloride, measured by the C-ToF-AMS for the four RF03 plume periods, as well as the RF01 plume average. Data are illustrated in Fig. 3.

\begin{tabular}{llllll}
\hline & \multicolumn{3}{c}{ RF03 Age } & RF01 Average \\
\hline & $\sim 2-4$ min & $\sim 32-39$ min & $\sim 52-62$ min & $\sim 81-88$ min & $\sim 17-30$ min \\
Black carbon (SP2) & $5[0.3-13]$ & $13[9-17]$ & $20[6-34]$ & $11[-16]$ & $2[0.04-6]$ \\
Organics & $89[80-98]$ & $71[55-94]$ & $66[23-100]$ & $61[32-98]$ & $86[28-100]$ \\
Nitrate & $3[1-3]$ & $8[2-10]$ & $8[1-12]$ & $7[1-12]$ & $5[1-9]$ \\
Sulfate & $0.6[0-1]$ & $4[3-5]$ & $4[2-6]$ & $17[8-27]$ & $4[2-6]$ \\
Ammonium & $0.3[0.2-0.4]$ & $2[1-4]$ & $2[0-5]$ & $3[0-13]$ & $2[0.1-3]$ \\
Chloride & $2[0.8-2]$ & $1[0.8-2]$ & $0.9[0.1-2]$ & $0.4[0-2]$ & $0.9[0.2-2]$ \\
\hline
\end{tabular}

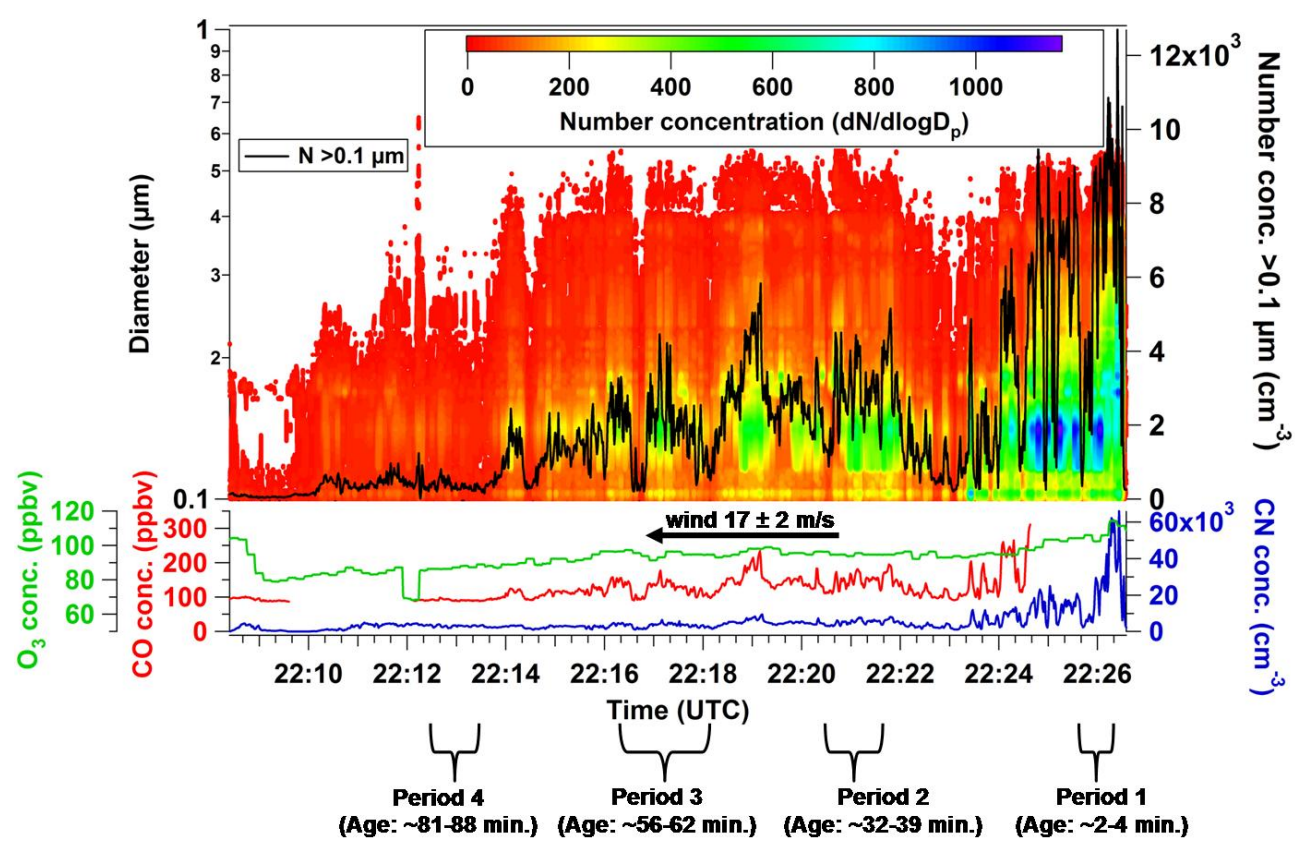

Fig. 2. RF03 temporal profiles of UHSAS size-resolved particle number concentrations are illustrated with associated concentrations of $\mathrm{CO}, \mathrm{O}_{3}, \mathrm{CN}$, and particles $>0.1 \mu \mathrm{m}$. Since $\mathrm{CO}$ data are not available for sampling closest to the burn source, maximum concentrations are estimated to be greater than the highest measured value of $311 \mathrm{ppbv}$, well above the average background air concentration of $92.6 \pm 0.9$ ppbv. The aircraft was flying into the wind, as indicated by the arrow; therefore, later sampling times correspond to sampling closer to the fire source. Discussed time periods and calculated smoke plume ages are noted.

maximum concentrations are estimated to be greater than the highest measured value of $311 \mathrm{ppbv}$, well above the background air concentration of $92.6 \pm 0.9 \mathrm{ppbv}$. Consistent with sampling closer to the burn source, $\mathrm{CN}$ number concentrations $\left(203-66061 \mathrm{~cm}^{-3}\right)$ were up to $\sim 76$ times greater than background conditions near the fire source $\left(865 \pm 570 \mathrm{~cm}^{-3}\right)$. Similarly, $\mathrm{N}_{>0.1}$ number concentrations $\left(17-12698 \mathrm{~cm}^{-3}\right)$ were elevated by up to a factor of $\sim 70$ compared to background concentrations $\left(183 \pm 55 \mathrm{~cm}^{-3}\right)$. As shown in Fig. 2, the particle diameter mode of the fresh smoke particles was $\sim 170 \mathrm{~nm}$, consistent with previously reported count median diameters of 100-160 nm for fresh smoke (Reid et al., 2005b). Although CO concentrations are not available for the entire plume, $\Delta x / \Delta \mathrm{CO}$ ratios were calculated for the remainder of the plume (see Fig. 2 for measurement periods). $\Delta \mathrm{CN} / \Delta \mathrm{CO}$ ratios ranged from $3-11520 \mathrm{~cm}^{-3} \mathrm{ppbv}^{-1}$; similar to RF01 plume sampling, a high correlation between $\Delta \mathrm{CN}$ and $\Delta \mathrm{CO}$ was not observed $\left(R^{2}=0.30\right)$. However, a high correlation was observed between $\Delta N_{>0.1}$ and $\Delta \mathrm{CO}$ $\left(R^{2}=0.93\right) . \mathrm{O}_{3}$ concentrations peaked at $114 \mathrm{ppbv}$ near the RF03 plume source, steadily decreased below even background conditions to $79 \mathrm{ppbv}$ within the plume, and rose back to $103 \mathrm{ppbv}$ with mixing with background air (prior to 22:09:14) (Fig. 2), suggesting initial $\mathrm{O}_{3}$ production, followed by $\mathrm{O}_{3}$ destruction within the plume. This contrasts the reported photochemical production of $\mathrm{O}_{3}$ in the presence of 
$\mathrm{NO}_{\mathrm{x}}$ observed within most biomass burning plumes during aging (e.g. Goode et al., 2000; Hobbs et al., 2003); however, periods of negative $\Delta \mathrm{O}_{3}$ have been observed for smoke ages $<5$ min (Hobbs et al., 2003) and low ultraviolet intensities (Stith et al., 1981). The production or loss of $\mathrm{O}_{3}$ is dependent on $\mathrm{NO}_{\mathrm{x}}$ concentrations, wherein $\mathrm{HO}_{2}$ radicals formed from the oxidation of $\mathrm{CO}$ can react with $\mathrm{O}_{3}$ to form $\mathrm{OH}$ rather than reacting with NO (Crutzen et al., 1999). In this study, the observed $\mathrm{O}_{3}$ destruction following an initial possible burst of $\mathrm{O}_{3}$ production is difficult to interpret without the measurement of other gas phase species, particularly $\mathrm{NO}_{\mathrm{x}}$.

The next sections describe the evolution of particle chemistry, as a function of particle age from the source of the burn. The fresh samples ( $\sim 2-4 \mathrm{~min}$ in age) are described first, followed by the more aged samples.

\subsection{Fresh biomass burning chemical signature}

The chemical composition of smoke plume particles was measured within the RF03 smoke plume from 22:25:57-22:26:31 UTC (Period 1), corresponding to a plume age of $\sim 2-4 \mathrm{~min}$. Overall, the fresh biomass burning particles were observed, by C-ToF-AMS, SP2, and AATOFMS, to be internal mixtures of organic carbon, elemental carbon, and potassium chloride and sulfate salts. Mass concentrations of submicron non-refractory species, including organic carbon, nitrate, sulfate, ammonium, and a fraction of chloride, were measured by the C-ToF-AMS; black carbon mass concentrations were measured by the SP2. The mixing of individual chemical species within single particles was measured by A-ATOFMS. Based on C-ToF-AMS and SP2 measurements, the average mass fractions [with uncertainty ranges] for these fresh (Period 1) smoke plume particles were estimated to be $89 \%$ [80-98\%] organics, $5 \%$ [0.3-13\%] black carbon (BC), $3 \%$ [1-3\%] nitrate, $0.6 \%$ [0$1 \%]$ sulfate, $0.3 \%[0.2-0.4 \%]$ ammonium, and $2 \%$ [0.82\%] chloride (Table 3 and Fig. 3). These results are in good agreement with previous measurements of fresh dry smoke particle composition: $\sim 80 \%$ OC, $\sim 5-9 \% \mathrm{BC}$, and $\sim 12-15 \%$ trace inorganics, such as potassium, sulfate, chloride, and nitrate (Reid et al., 2005b). It is important to note that traditional filter-based $\mathrm{BC}$ measurements can overestimate BC mass due to interferences from organics (Subramanian et al., 2007; Subramanian et al., 2010). The mass fractions calculated herein assume that refractory species not measured by the C-ToF-AMS and SP2 contribute only minor fractions to the total submicron mass, providing upper limits for the species mass fractions. Refractory species, such as potassium salts and mineral dust, are not measured by the C-ToF-AMS, which operated with a vaporizer temperature of $550-560^{\circ} \mathrm{C}$. Volatilization rates of $\mathrm{KCl}$ and $\mathrm{K}_{2} \mathrm{SO}_{4}$ become important at $700-800^{\circ} \mathrm{C}$ and above $1000^{\circ} \mathrm{C}$, respectively (Knudsen et al., 2004). Previous measurements of burning dry sagebrush have shown contributions of potassium and chloride up to $\sim 24 \%$ and $\sim 10 \%$ of the total

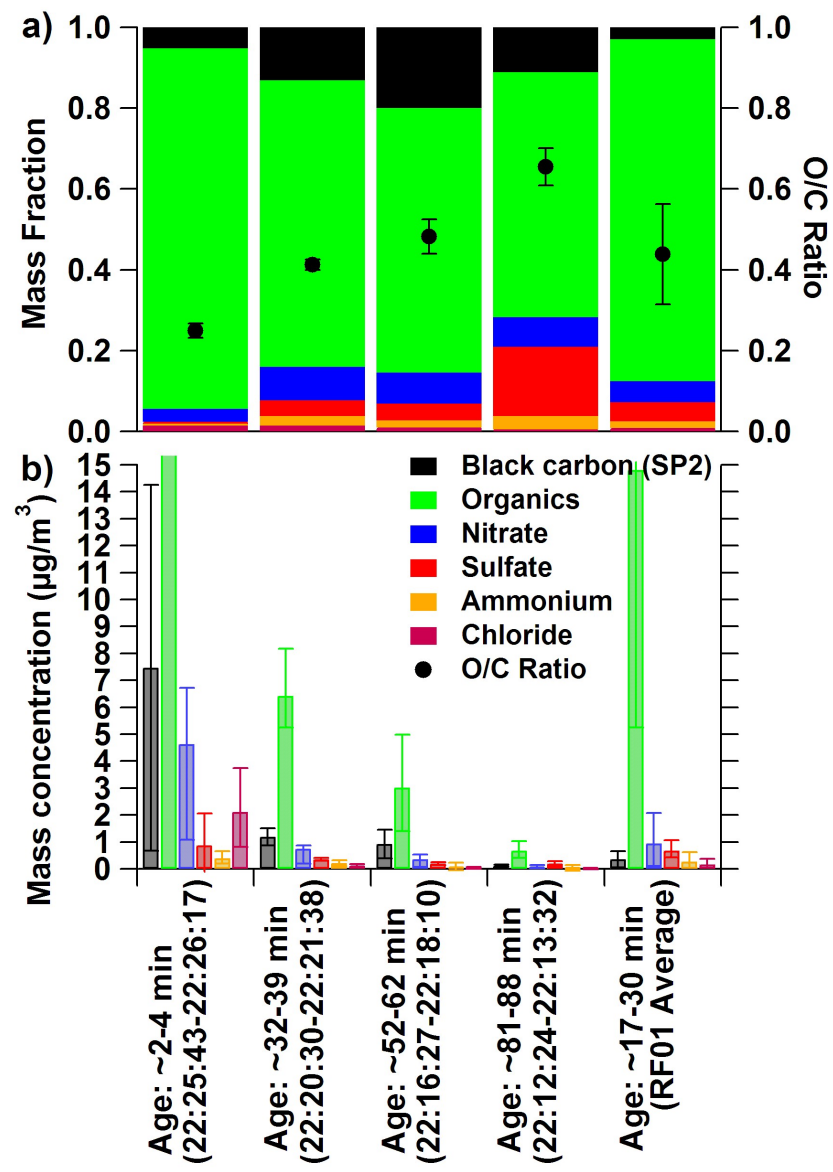

Fig. 3. (a) Submicron aerosol mass fractions considering black carbon, measured by the SP2, as well as non-refractory organics, sulfate, nitrate, ammonium, and chloride, measured by the C-ToFAMS for the four RF03 plume periods, as well as the RF01 plume average. Uncertainty ranges in the mass fractions are noted in Table 3. The $\mathrm{O} / \mathrm{C}$ ratio of the organics, measured by the C-ToF-AMS, is also illustrated. (b) Submicron average species mass concentrations measured by the SP2 and C-ToF-AMS; note that average organic mass concentrations during Period 1 (age $\sim 2-4 \mathrm{~min}$ ) and RF01 are offscale: 129 [88-195] $\mu \mathrm{g} \mathrm{m}^{-3}$ and 15 [5-33] $\mathrm{g} \mathrm{m}^{-3}$, respectively.

aerosol mass, respectively, which were significantly higher than other tested fuels (Chen et al., 2007). The presence of these species within the fresh biomass burning particles was confirmed by A-ATOFMS. In addition, refractory OC, shown previously to contribute to biomass burning aerosols (Clarke et al., 2007), may not be measured by the C-ToF-AMS.

Throughout RF03 plume sampling, $84 \pm 1 \%$ of the submicron $(\sim 0.1-1.0 \mu \mathrm{m})$ particles by number were identified by A-ATOFMS as having one dominant biomass burning mass spectral signature, characterized by potassium internally mixed with carbonaceous species (Silva et al., 1999; Hudson et al., 2004). The average positive and negative ion mass spectra of the fresh (Period 1) biomass burning 


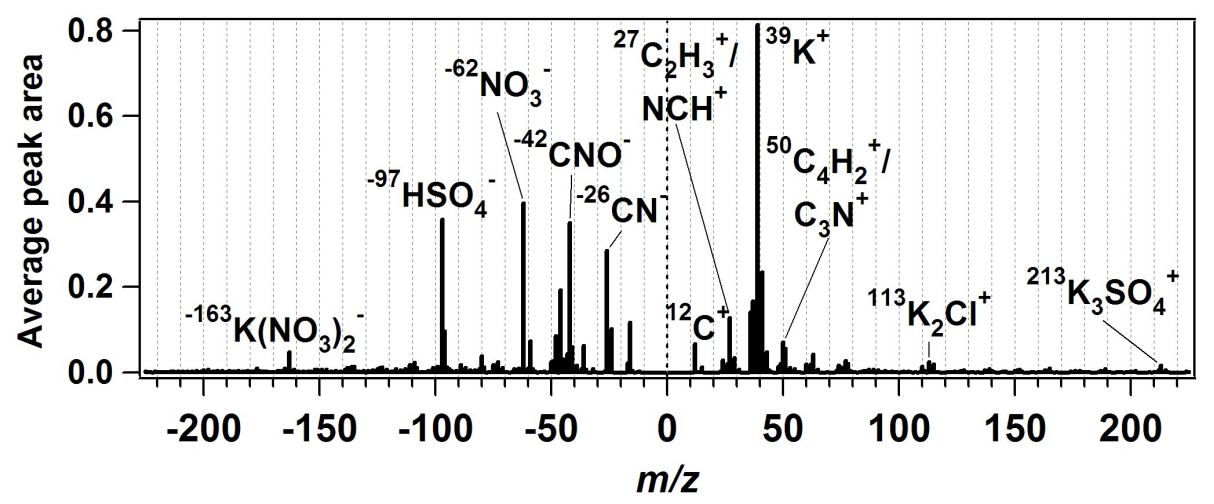

Fig. 4. A-ATOFMS average mass spectrum of 52 fresh biomass burning particles sampled during RF03 plume Period 1.

particles are shown in Fig. 4. The particles were characterized by potassium $\left(m / z 39 / 41\left(\mathrm{~K}^{+}\right), 78\left(\mathrm{~K}_{2}^{+}\right)\right)$, organic carbon (OC) and organic nitrogen $\left(m / z 27\left(\mathrm{C}_{2} \mathrm{H}_{3}^{+} / \mathrm{NCH}^{+}\right)\right.$, $\left.37\left(\mathrm{C}_{3} \mathrm{H}^{+}\right), 50\left(\mathrm{C}_{4} \mathrm{H}_{2}^{+} / \mathrm{C}_{3} \mathrm{~N}^{+}\right),-26\left(\mathrm{CN}^{-}\right),-42\left(\mathrm{CNO}^{-}\right)\right)$, elemental carbon (EC) $\left(\mathrm{C}_{n}^{+/-}\right)$, nitrate $\left(\mathrm{m} / z-46\left(\mathrm{NO}_{2}^{-}\right)\right.$, $\left.-62\left(\mathrm{NO}_{3}^{-}\right)\right)$, and sulfate $\left(\mathrm{m} / z-80\left(\mathrm{SO}_{3}^{-}\right),-97\left(\mathrm{HSO}_{4}^{-}\right)\right)$, similar to observations by Silva et al. (1999) in laboratory studies. Potassium sulfate $\left(m / z 213\left(\mathrm{~K}_{3} \mathrm{SO}_{4}^{+}\right)\right)$, potas-

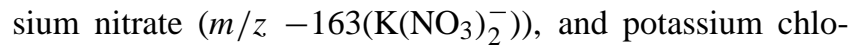
ride $\left(m / z \quad 113 / 115\left(\mathrm{~K}_{2} \mathrm{Cl}^{+}\right),-109 /-111\left(\mathrm{KCl}_{2}^{-}\right)\right)$were also present in $\sim 63-73 \%$ of the fresh biomass burning particles, likely due to the contribution from flaming combustion (see Sect. 3.1), as potassium concentrations have been observed to decrease exponentially from flaming to smoldering combustion (Cahill et al., 2008). While previous studies have shown primarily $\mathrm{KCl}$ in fresh biomass burning aerosols with little contribution from sulfur species ( $\mathrm{Li}$ et al., 2003), the presence of $\mathrm{K}_{2} \mathrm{SO}_{4}$ has been suggested to be a function of fuel composition and burn conditions (Pósfai et al., 2003). Consistent with the very low mass fraction of ammonium observed by the C-ToF-AMS, only $8 \pm 4 \%$ of the fresh biomass burning particles were observed by A-ATOFMS to be internally mixed with ammonium $\left(\mathrm{m} / z 18\left(\mathrm{NH}_{4}^{+}\right)\right)$. Despite the low mass fractions of nitrate and sulfate observed by the CToF-AMS during Period 1, $100 \%$ of these fresh (Period 1) biomass burning particles by number were internally mixed with nitrate $\left(m / z-62\left(\mathrm{NO}_{3}^{-}\right)\right)$and $92 \pm 4 \%$ contained sulfate $\left(m / z-97\left(\mathrm{HSO}_{4}^{-}\right)\right)$, as measured by A-ATOFMS. This is a significant finding, showing that all freshly-emitted biomass burning particles contain some hygroscopic material at the point of emission, even if initially at low mass concentrations. This has important ramifications for cloud formation in regions of major fires.

The C-ToF-AMS size distribution of organics during RF03 Period 1 shows the mass diameter peaking at $\sim 270 \mathrm{~nm}$ $d_{\text {va }}$. The organics were characterized by an $\mathrm{O} / \mathrm{C}$ ratio of $0.25 \pm 0.02$, which is in excellent agreement with fresh laboratory biomass burning organics $(\mathrm{O} / \mathrm{C}$ ratio 0.15 to 0.39$)$
(Weimer et al., 2008; Grieshop et al., 2009). An ion peak at $\mathrm{m} / \mathrm{z}$ 60, attributed to levoglucosan (Schneider et al., 2006; Alfarra et al., 2007), a degradation product of cellulose (Simoneit et al., 1999), comprised $1.09 \pm 0.04 \%$ of the total organic signal, in agreement with previous AMS observations of 1-7\% (Weimer et al., 2008; Grieshop et al., 2009). Further, laboratory measurements of levoglucosan/OC mass ratios for $\mathrm{PM}_{2.5}$ resulting from sage combustion were previously observed to be $1.6-4.1 \%$ (Sullivan et al., 2008). In agreement, A-ATOFMS measurements suggested that $40 \pm 7 \%$ of the fresh biomass burning particles contained levoglucosan $\left(\mathrm{m} / \mathrm{z}-71\left(\mathrm{C}_{3} \mathrm{H}_{3} \mathrm{O}_{2}^{-}\right)\right)$and $60 \pm 7 \%$ contained oxalate $\left(\mathrm{m} / z-89\left(\mathrm{C}_{2} \mathrm{O}_{4} \mathrm{H}^{-}\right)\right)$(Sullivan and Prather, 2007), consistent with previous filter-based observations of Gao et al. (2003).

Consistent with the results discussed herein, previous single-particle mass spectrometry observations of a $\sim 2 \mathrm{~h}$ old large forest fire plume showed over $90 \%$ of the particles contained potassium, being classified as having a biomass burning mass spectral signature (Hudson et al., 2004). Similarly, using electron microscopy, organic particles with crystalline potassium salt inclusions were observed to be the most abundant type in smoke plumes (Pósfai et al., 2003). Within the sampled RF01 and RF03 smoke plumes, $33 \pm 4 \%$ and $16 \pm 1 \%$, respectively, of the submicron particles were not classified by the biomass burning mass spectral signature. All EC was observed by the A-ATOFMS to be internally mixed with $\mathrm{OC}$, in agreement with the Hudson et al. (2004) study. Any EC particles smaller than $70 \mathrm{~nm}\left(d_{\mathrm{va}}\right)$, not examined in this study, would comprise a minor fraction of the particle number and mass fractions, given the size mode at $\sim 170 \mathrm{~nm}$ (Fig. 2). This A-ATOFMS observation of EC internally mixed within the biomass burning particles is consistent with the RF03 SP2 measurements, which showed that $\sim 47 \%$ of the measured BC (defined here as $\mathrm{EC}+$ polycyclic aromatic hydrocarbons) particles $(0.08-$ $0.22 \mu \mathrm{m}$ BC mass equivalent diameter) were thickly-coated during Period 1 (aerosol age $\sim 2-4 \mathrm{~min}$ ). This is consistent with the smoldering component of the RF03 prescribed burn. 


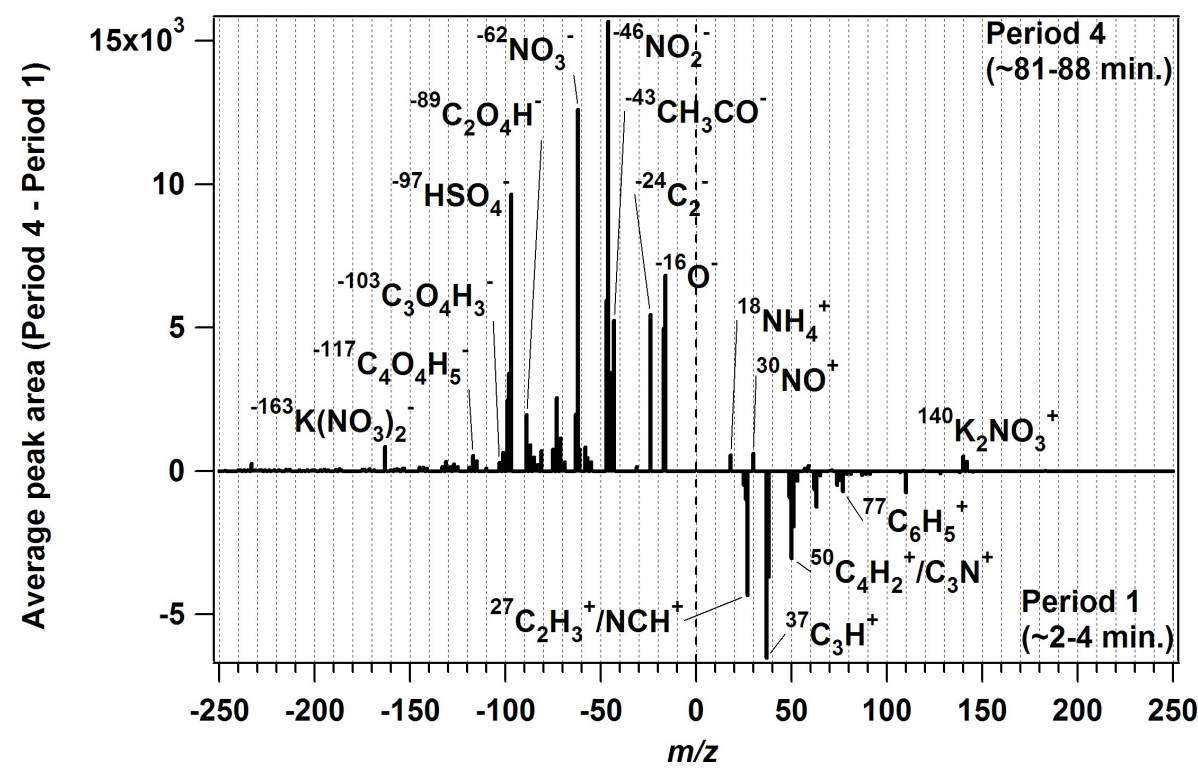

Fig. 5. A-ATOFMS average positive and negative ion mass spectra for biomass burning particles during RF03 Period 1 (age $\sim 2-4$ min) subtracted from biomass burning particles during RF03 Period 4 (age $\sim 81-88 \mathrm{~min}$ ). Positive intensity ion peaks indicate species added during aging of the individual biomass burning particles; negative intensity ion peaks indicate species with higher ion intensities within the fresh particles. Only ion peaks above $95 \%$ confidence limits following subtraction are shown.

For the RF03 plume, an average of $2 \%$ of the submicron particles by number were classified by the A-ATOFMS as OC internally mixed with sulfate and nitrate; a larger fraction $(28 \pm 4 \%)$ of these OC particles were observed within the RF01 plume. For the RF03 and RF01 plumes, $0.7 \pm 0.2 \%$ and $2 \pm 1 \%$, respectively, of the particles were classified as EC mixed with OC, sulfate, and nitrate. Mineral dust, which is lofted from the ground during fires, contributed $1.4 \pm 0.3 \%$ and $2 \pm 1 \%$, respectively to the RF01 and RF03 plume submicron particles by number. This is consistent with the minor contributions observed previously by Li et al. (2003). Finally, $11 \pm 1 \%$ and $2 \pm 1 \%$ of the particles in the RF01 and RF03 plumes, respectively, produced only negative ion mass spectra containing nitrate and sulfate; the origin of these particles is still being investigated. They could be representative of particles with thicker nitrate coatings due to gas-to-particle condensation occurring at cooler temperatures.

\subsection{Aging of smoke plume particles}

RF03 plume sampling corresponded to particles ranging from $\sim 2$ min to $\sim 2 \mathrm{~h}$ in age; whereas, the single, shorter RF01 plume sampling period corresponded to $\sim 17-30 \mathrm{~min}$ aged particles (Table 2). Thus, aging of the RF03 plume particles across the plume is discussed herein and compared to the RF01 plume average. A comparison of the AATOFMS average mass spectral signatures for the RF03 Period 1 and Period 4 biomass burning particles is shown in Fig. 5. As expected, excess black carbon mass concentrations $\left(\triangle \mathrm{BC}=[\mathrm{BC}]-\left[\mathrm{BC}_{\text {background }}\right]\right)$, measured by the SP2, were linearly correlated with $\Delta \mathrm{CO}\left(R^{2}=0.79\right.$, Fig. 6a) through the RF03 smoke plume, showing that BC mass concentration changes were consistent with dilution. Average $\triangle \mathrm{BC} / \triangle \mathrm{CO}$ was observed to be $0.018 \pm 0.001 \mu \mathrm{g} \mathrm{m}^{-3} \mathrm{ppbv}^{-1}$, slightly higher than previously observed by Hobbs et al. (2003) for a savanna fire $\left(0.0056-0.0105 \mu \mathrm{g} \mathrm{m}^{-3} \mathrm{ppbv}^{-1}\right)$ using a filterbased optical transmission technique to measure BC. BC mass fractions were similar (within uncertainties) for all time periods, including the RF01 plume (Table 3).

\subsubsection{Organics}

Excess organic mass concentrations (above background conditions), measured by the C-ToF-AMS, were linearly correlated with $\triangle \mathrm{CO}\left(R^{2}=0.95\right.$, Fig. $\left.6 \mathrm{~b}\right)$ for the RF03 plume. However, a straightforward dilution did not occur as the organic aerosol composition changed within the plume with the $\mathrm{O} / \mathrm{C}$ ratio increasing with decreasing $\Delta \mathrm{CO}$ (Fig. 6c), similar to the observations of Capes et al. (2008). Over the course of RF03 plume sampling, the $\mathrm{O} / \mathrm{C}$ ratio increased from $0.25 \pm 0.02$ for an aerosol age of $\sim 2-4 \mathrm{~min}$ to $0.65 \pm 0.05$ for an aerosol age of $\sim 81-88 \mathrm{~min}$ (Fig. 3a). The intermediate $\mathrm{O} / \mathrm{C}$ ratio of $0.44 \pm 0.12$ measured for the $\mathrm{RF} 01$ plume (aerosol age $\sim 17-30 \mathrm{~min}$ ) is consistent with the oxidation timescale observed for the RF03 plume (Fig. 3a). The increasing $\mathrm{O} / \mathrm{C}$ ratio with aging is consistent with an increasingly oxygenated organic aerosol (Aiken et al., 2008; Heald et al., 2010). Hawkins and Russell (2010) observed the formation of carboxylic acid groups with loss of ketone groups, significantly increasing the $\mathrm{O} / \mathrm{C}$ ratio, in the aging of biomass 


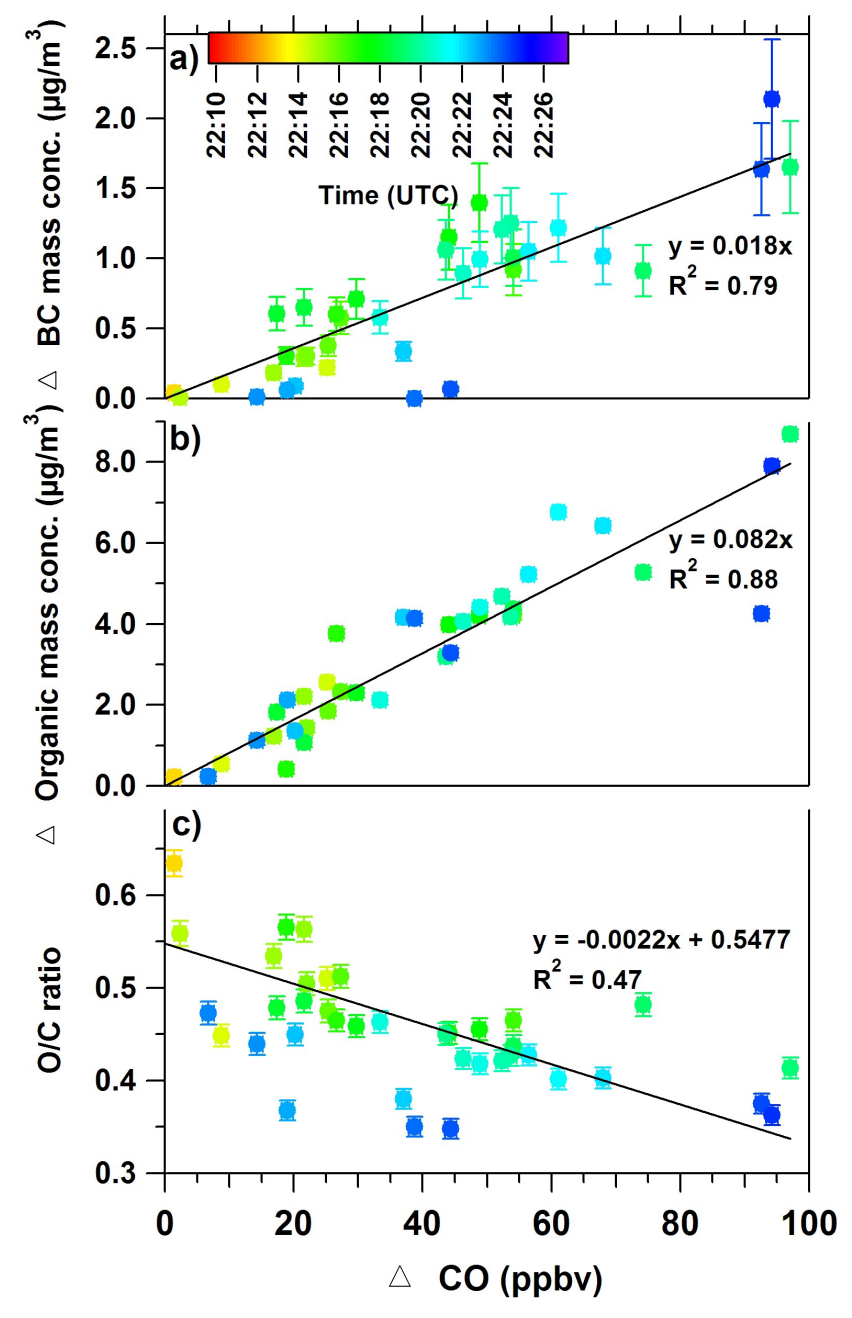

Fig. 6. Excess $(\Delta)$ (a) SP2 black carbon (BC) mass concentrations and (b) C-ToF-AMS organic mass concentrations versus $\triangle \mathrm{CO}$ concentrations as a function of RF03 plume sample time. (c) C-ToFAMS organic $\mathrm{O} / \mathrm{C}$ ratio versus $\triangle \mathrm{CO}$ as a function of RF03 plume sample time. Note that $\mathrm{CO}$ data were not available over the entire RF03 smoke plume (see Fig. 2).

burning organic aerosol; however, the timescale of oxygen uptake via heterogeneous reaction with $\mathrm{OH}$ alone is too slow to explain the increased $\mathrm{O} / \mathrm{C}$ ratios here (DeCarlo et al., 2008; Kessler et al., 2010). Considering the O/C ratio of the nearby background organic aerosol $(0.61-0.95), \sim 25 \%$ of the observed bulk $\mathrm{O} / \mathrm{C}$ ratio increase from RF03 Periods $1-3$ is estimated to be due to mixing with background aerosol, using the method of Murphy et al. (2009). For Period 4 , this dilution influence increases to over $50 \%$; however, this estimate is highly uncertain given the low loadings of this period and the background, as well as the still high abundance of biomass burning particles, measured by A-ATOFMS. Since the $\Delta$ organic/ $\triangle \mathrm{CO}$ ratio was relatively constant, it is likely the aerosol transformed by: (1) repartitioning of more volatile, less oxygenated organic species to the gas phase following heterogeneous reactions and/or dilution, resulting in a more oxidized organic aerosol (Kroll et al., 2009), as well as (2) condensation of oxidized organics (Donahue et al., 2006), such as dicarboxylic acids, as discussed below. As noted by Capes et al. (2008) and Hennigan et al. (2011) for similar observations of the aging of biomass burning organic aerosol, the mechanisms must balance one another to keep the $\Delta$ organic/ $\Delta C O$ ratio constant.

Consistent with the increased fraction of oxidized organics measured by C-ToF-AMS, A-ATOFMS measurements of biomass burning particles show increased ion peaks areas, proportional to mass, associated with oxidized organics $\left(\mathrm{m} / \mathrm{z} 43\left(\mathrm{CH}_{3} \mathrm{CO}^{+}\right)\right)$, and decreased ion peak areas for non-oxygenated organics (e.g. $m / z \quad 27\left(\mathrm{C}_{2} \mathrm{H}_{3}^{+}\right)$, $\left.37\left(\mathrm{C}_{3} \mathrm{H}^{+}\right), \quad 50\left(\mathrm{C}_{4} \mathrm{H}_{2}^{+}\right), 77\left(\mathrm{C}_{6} \mathrm{H}_{5}^{+}\right)\right)$with aging, as shown in Fig. 5. Further, the $\mathrm{C}-\mathrm{ToF}-\mathrm{AMS} \mathrm{O} / \mathrm{C}$ ratio was correlated $\left(R^{2}=0.5\right)$ with the A-ATOFMS oxidized organics/total organics ratio, calculated by dividing the relative peak area of $m / z 43\left(\mathrm{CH}_{3} \mathrm{CO}^{+}\right)$by the sum of the relative peak areas of representative organic ions $\left(m / z 27\left(\mathrm{C}_{2} \mathrm{H}_{3}^{+}\right)\right.$, $\left.29\left(\mathrm{C}_{2} \mathrm{H}_{5}^{+}\right), 37\left(\mathrm{C}_{3} \mathrm{H}^{+}\right), 43\left(\mathrm{CH}_{3} \mathrm{CO}^{+}\right)\right)$, as defined by Spencer and Prather (2006). A-ATOFMS measurements show the accumulation of organic acids on biomass burning particles as the plumes aged (Fig. 5). In general, organic acids have been shown to account for $>3 \%$ of particle mass in aged smoke particles compared to $<1 \%$ in fresh smoke (Reid et al., 2005b). The number fraction of biomass burning particles containing oxalate $\left(m / z-89\left(\mathrm{C}_{2} \mathrm{O}_{4} \mathrm{H}^{-}\right)\right)$increased from $60 \pm 7 \%$ to $94 \pm 4 \%$ with aging from $\sim 2-4$ min to $\sim 81-$ 88 min within the RF03 plume, with the RF01 plume showing an intermediate fraction ( $87 \pm 3 \%)$, as expected. Concurrent with the increased fraction of particles internally mixed with oxalate, the average $m / z-89$ peak area, which is proportional to oxalate mass, also increased by a factor of $6 \pm 4$, as illustrated in Fig. 5. Similarly, the number fractions of biomass burning particles internally mixed with malonate $\left(m / z-103\left(\mathrm{C}_{3} \mathrm{O}_{4} \mathrm{H}_{3}^{-}\right)\right)$and succinate $\left(m / z-117\left(\mathrm{C}_{4} \mathrm{O}_{4} \mathrm{H}_{5}^{-}\right)\right)$ (Sullivan and Prather, 2007) also increased significantly from $15 \pm 5 \%$ and $25 \pm 6 \%$, respectively, to $66 \pm 8 \%$ and $77 \pm 7 \%$, respectively, with aging from $\sim 2-4 \mathrm{~min}$ to $\sim 81-88 \mathrm{~min}$ within the RF03 plume, with the RF01 plume showing an intermediate fraction. Similar to oxalate, the A-ATOFMS malonate and succinate peak areas, proportional to mass, increased by factors of $5 \pm 4$ and $8 \pm 5$, respectively, with aging, as shown in Fig. 5. These data are consistent with previous smoke plume observations of the concentrations of oxalate and succinate increasing by at least an order of magnitude after $\sim 40$ min of aging, although malonate was absent from most of the savanna fire aerosols (Gao et al., 2003). Gao et al. (2003) concluded that the most likely pathways for the addition of dicarboxylic acids during biomass aging are the oxidation of larger organic molecules at the particle surface through heterogeneous reactions or aquous reactions inside the particle. However, Yokelson et al. (2009) 
observed formation of gas-phase organic acids within aging smoke plumes. Thus, additional laboratory studies under relevant ambient conditions are required to further understand the mechanism(s) of plume aging resulting in a more oxidized organic aerosol. These studies should strive to reproduce relevant oxidant and precursor concentrations, as well as dilution conditions and temperatures.

Levoglucosan, a degradation product of cellulose, is often used as a marker of fresh biomass burning (Simoneit et al., 1999). $\sim 40-65 \%$ of the biomass burning particles, by number measured by the A-ATOFMS, were characterized by $m / z-71\left(\mathrm{C}_{3} \mathrm{H}_{3} \mathrm{O}_{2}^{-}\right)$, previously observed to be a marker of levoglucosan (Silva et al., 1999). The contribution of the C-ToF-AMS marker of levoglucosan, $\mathrm{m} / \mathrm{z} 60$, to the total organic aerosol decreased from $1.09 \pm 0.04 \%$ to $0.3 \pm 0.5 \%$ with aging from $\sim 2-4 \mathrm{~min}$ to $\sim 81-88 \mathrm{mins}$ within the RF03 plume. However, for the RF01 plume average (age $\sim 17-30 \mathrm{~min}$ ), the $\mathrm{m} / \mathrm{z} 60$ fraction was higher at $1.3 \pm 0.1 \%$. While atmospheric lifetimes of levoglucosan have been estimated at $\sim 0.7-11$ days (Hennigan et al., 2010; Kessler et al., 2010), recently Hennigan et al. (2011) observed a rapid decay, five times faster than the $\mathrm{OH}$ collision rate, of levoglucosan in the photooxidation of open biomass burning emissions.

\subsubsection{Chloride}

Gao et al. (2003) observed chloride mass concentrations to decrease by a factor of two from $\sim 7-40 \mathrm{~min}$ of aging; however, the possible decreasing trend was unclear due to a lack of data points. In this study, average C-ToF-AMS non-refractory chloride mass fractions were within standard deviations for all plume periods (Table 3). Electron microscopy studies have noted the transformation of $\mathrm{KCl}$ to $\mathrm{K}_{2} \mathrm{SO}_{4}$ and $\mathrm{KNO}_{3}$ during aging ( $\mathrm{Li}$ et al., 2003; Yokelson et al., 2009). Similarly, the A-ATOFMS number fraction of biomass burning particles with the potassium chloride ion peak $m / z 113\left(\mathrm{~K}_{2} \mathrm{Cl}^{+}\right)$decreased slightly with plume aging from $67 \pm 7 \%$ to $46 \pm 8 \%$ with aging from $\sim 2-4 \mathrm{~min}$ to $\sim 81-88$ min within the RF03 plume; however, average $m / z 113\left(\mathrm{~K}_{2} \mathrm{Cl}^{+}\right)$and $m / z-35\left(\mathrm{Cl}^{-}\right)$peak areas, proportional to mass, were within uncertainties for all periods, similar to the C-ToF-AMS data. For the RF01 plume biomass burning particles, $80 \pm 4 \%$ by number were characterized by $m / z 113\left(\mathrm{~K}_{2} \mathrm{Cl}^{+}\right)$, suggesting that the fraction of particles containing potassium chloride salts likely varies for different fuels and fire conditions. In fact, different chloride emission factors were observed by McMeeking et al. (2009) for different fuels, with sagebrush having one of the highest emission factors measured. Indeed, the RF01 fire was characterized by a higher sagebrush fuel fraction $(\sim 90 \%)$ compared to that of the RF03 plume ( $75 \%)$ (Table 1$)$.

\subsubsection{Ammonium, nitrate, and sulfate}

During smoke plume aging, aerosols accumulate sulfate and nitrate by acquiring $\mathrm{NO}_{\mathrm{x}}$ and $\mathrm{SO}_{2}$ oxidation products (e.g. Gao et al., 2003; Hudson et al., 2004; Yokelson et al., 2009). In particular, several studies have shown the transformation of $\mathrm{KCl}$ to $\mathrm{K}_{2} \mathrm{SO}_{4}$ and $\mathrm{KNO}_{3}$ during plume aging (Gaudichet et al., 1995; Li et al., 2003; Yokelson et al., 2009). Hobbs et al. (2003) and Gao et al. (2003) observed significant increases in nitrate mass concentrations with plume aging of $\sim 40 \mathrm{~min}$. During the RF03 smoke plume, excess nitrate and ammonium (plume minus background concentrations), measured by the C-ToF-AMS, were positively correlated $\left(R^{2}=0.66\right)$, suggesting the addition of ammonium nitrate with aging, confirmed by the A-ATOFMS singleparticle mixing (Fig. 5). Initial increases in the mass fractions of ammonium and nitrate were measured from $0.3 \%$ [0.2-0.4\%] and $2 \%[1-4 \%]$, respectively, for an aerosol age of 2-4 min (Period 1 ) to $3 \%$ [1-3\%] and $8 \%$ [2-10\%], respectively, for an age of $\sim 32-39 \min ($ Period 2$)$, after which the mass fractions stayed constant (Table 3 and Fig. 3a). Correspondingly, the number fraction of biomass burning particles, measured by A-ATOFMS, internally mixed with ammonium $\left(\mathrm{m} / \mathrm{z} 18\left(\mathrm{NH}_{4}^{+}\right)\right)$increased from $8 \pm 4 \%$ to $28 \pm 4 \%$ from Period 1 to Period 2 with increased ammonium peak areas for the aged particles, as shown in Fig. 5. Nearly $100 \%$ of all biomass burning particles, measured by the A-ATOFMS, were internally mixed with nitrate; nitrate $\left(\mathrm{m} / z-62\left(\mathrm{NO}_{3}^{-}\right)\right)$ peak area increased by a factor of $3 \pm 1$ from Period 1 to Period 2 and then stayed constant, consistent with the C-ToF-AMS observations. Similarly, the number fraction of biomass burning particle mass spectra characterized by

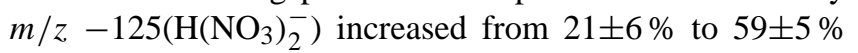
from Period 1 to Period 2, indicative of increasing nitrate mass on the individual particles. While the number fraction of biomass burning particles internally mixed with potassium

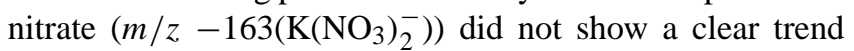
with aging, the ion peak area increased by a factor of $3 \pm 2$ with aging from RF03 Period 1 (age $\sim 2-4 \mathrm{~min}$ ) to Period 4 (age $\sim 81-88 \mathrm{~min}$ ).

Liu et al. (2000) noted excess sulfate beyond that required for chloride replacement during smoke plume aging. During RF03 plume aging, the C-ToF-AMS sulfate mass fraction increased from $0.6 \%$ [0-1\%] with $\sim 2-4$ min of aging to $17 \%$ [8-27\%] following $\sim 81-88 \mathrm{~min}$ of aging (Table 3 and Fig. 3a). Accordingly, excess sulfate was not correlated with $\Delta \mathrm{CO}$ or ammonium. Nearly $100 \%$ of all biomass burning particles were internally mixed with sulfate during all periods, as measured by A-ATOFMS; however, sulfate $\left(\mathrm{m} / z-97\left(\mathrm{HSO}_{4}^{-}\right)\right)$peak areas increased by a factor of $3 \pm 2$ with aging from $\sim 2-4 \mathrm{~min}$ to $\sim 81-88 \mathrm{~min}$, consistent with the C-ToF-AMS results. Previously, Hudson et al. (2004), using single-particle mass spectrometry, measured higher median sulfate peak areas for aged, or transported, biomass burning events compared to fresh biomass burning particles. 
The number fraction of biomass burning particles internally mixed with potassium sulfate $\left(m / z 213\left(\mathrm{~K}_{3} \mathrm{SO}_{4}^{+}\right)\right)$did not show a clear trend with aging.

During RF03 Period 1, the calculated C-ToF-AMS $\mathrm{NH}_{4 \text { meas }}^{+} / \mathrm{NH}_{4 \text { neu }}^{+}$ratio (Zhang et al., 2007) was calculated to be $0.40 \pm 0.08$, indicating the presence of acidic particles. The A-ATOFMS number fraction of acidic particles increased with aging, as evidenced by the trend of the sulfuric acid ion marker $m / z-195\left(\mathrm{H}_{2} \mathrm{SO}_{4} \mathrm{HSO}_{4}^{-}\right)$) (Denkenberger et al., 2007; Yao et al., 2011). The number fraction of biomass burning particles internally mixed with sulfuric acid increased from $8 \pm 4 \%$ at $\sim 2-4$ min of aging to $28 \pm 4 \%$ at $\sim 32-39 \mathrm{~min}$ and then stayed relatively constant with aging to $\sim 81-88 \mathrm{~min}$. For a plume age of $\sim 17-30 \mathrm{~min}, 12 \pm 3 \%$ of RF01 biomass burning particles were mixed with sulfuric acid.

\subsection{Cloud activation properties}

\subsubsection{Cloud condensation nuclei}

Wildfires serve as large sources of CCN (Hobbs and Radke, 1969; Eagan et al., 1974) with a wide range of hygroscopicities (Petters et al., 2009a; Carrico et al., 2010). During RF03 plume aging from $\sim 2-4 \mathrm{~min}$ (Period 1) to $\sim 81-88 \mathrm{~min}$ (Period 4$), \mathrm{CCN}$ number concentrations, measured at a supersaturation of $0.5 \%$, ranged from $\sim 15000 \mathrm{~cm}^{-3}$ to $\sim 350 \mathrm{~cm}^{-3}$ (Table 4) primarily due to dilution. Background RF03 $\mathrm{CCN}_{0.5 \%}$ concentrations were $\sim 230 \mathrm{~cm}^{-3}$. For an assessment of $\mathrm{CCN}$ efficiency, the fractions of $\mathrm{CCN}$ relative to the $\mathrm{N}_{>0.1}$ and total $\mathrm{CN}(>13 \mathrm{~nm})$ concentrations were calculated. For all periods of plume sampling, $\mathrm{CCN}_{0.5 \%} / \mathrm{N}_{>0.1}$ ratios were greater than 1 , suggesting activation at $0.5 \%$ supersaturation of all particles greater than $100 \mathrm{~nm}$ in diameter throughout the smoke plumes. However, it should be noted that smaller, more hygroscopic particles may have activated before larger, less hygroscopic particles, as observed previously for laboratory smoke particles (Petters et al., 2009a). For the youngest smoke particles (Period 1), the average $\mathrm{CCN}_{0.5 \%} / \mathrm{CN}$ ratio was $1.12 \pm 0.26$, showing that nearly all particles activated at $0.5 \%$ supersaturation (Table 4 ), as predicted by Petters et al. (2009a) based on laboratory measurements and modeling. Previously, sagebrush smoke particles were observed by Petters et al. (2009a) to be amongst the most hygroscopic of 24 tested biomass fuels. Lower $\mathrm{CCN}_{0.5 \%} / \mathrm{CN}$ ratios were observed for RF03 Periods 2 and $3(\sim 59 \%)$, as well as for the RF01 plume $(\sim 28 \%)$, despite higher mass fractions of non-refractory sulfate and nitrate measured by the C-ToF-AMS. The lowest $\mathrm{CCN}_{0.5 \%} / \mathrm{CN}$ ratio $(\sim 11 \%)$ was measured during Period 4 and is associated with the increased number concentration of $<100 \mathrm{~nm}$ particles (likely from mixing with background air). It is generally observed that CCN efficiency increases with smoke particle aging (Andreae and Rosenfeld, 2008). Condensation of components with low hygroscopicity still decreases the critical supersaturation due to the increase in particle size (Petters et al., 2009a); therefore, increased CCN activity with particle aging is expected. Overall, the biomass burning particles were found to be highly $\mathrm{CCN}$ active, particularly in contrast to the background aerosol.

\subsubsection{Ice nuclei}

IN can be produced by biomass combustion events (Hobbs and Locatelli, 1969; Pueschel and Langer, 1973), but the exact source of IN remains unidentified both in the laboratory (Petters et al., 2009b) and in the atmosphere (Twohy et al., 2010; Stith et al., 2011). For RF03 plume sampling during Periods 1-3, average IN number concentrations, measured at a CFDC processing temperature of $-32{ }^{\circ} \mathrm{C}$ for condensation/immersion freezing nucleation, ranged from $\sim 22 \mathrm{~L}^{-1}$ to $\sim 10 \mathrm{~L}^{-1}$ (Table 4$)$. Higher IN concentrations $(\sim 30$ and $\sim 47 \mathrm{~L}^{-1}$, respectively) were measured during RF03 Period 4 and within the RF01 plume when the aerosol was processed at a slightly colder temperature $\left(-34^{\circ} \mathrm{C}\right)$. It is not known to what extent these results represent burn variability impacting IN production versus the modestly colder processing temperature that could favor an increase in IN concentration (Möhler et al., 2007). Overall, IN concentrations within the smoke plumes were enhanced compared to background concentrations of $\sim 6-8 \mathrm{~L}^{-1}$ for RF01 and $\sim 4-6 \mathrm{~L}^{-1}$ for RF03.

During all plume sampling, the maximum observed IN/CN ratio $(0.008 \%)$ was $<0.01 \%$, estimated by Petters et al. (2009b) as likely to strongly perturb IN concentrations on a regional scale. IN $/ \mathrm{N}_{>0.1}$ ratios were also less than $0.01 \%$ with $\mathrm{IN} / \mathrm{N}_{>0.5}$ ratios of $\sim 0.03-0.07 \%$ and $\sim 0.2-2 \%$ for CFDC measurements at $-32{ }^{\circ} \mathrm{C}$ and $-34^{\circ} \mathrm{C}$, respectively. Previous laboratory measurements of immersion/condensation freezing of sagebrush combustion aerosols at $-30^{\circ} \mathrm{C}$ showed a IN/CN ratio below $0.0025 \%$ for five out of seven samples, with a ratio of $0.25 \%$ for two out of seven samples (Petters et al., 2009b), consistent with the ratios measured herein. Considering plume $0.1-1.0 \mu \mathrm{m}$ unreacted mineral dust number fractions, measured by the AATOFMS, of $<0.4 \%$ and activation of $\sim 6-20 \%$ of mineral dust as ice nuclei (Field et al., 2006; Prenni et al., 2009), an IN $/ \mathrm{N}_{>0.1}$ fraction of $<0.08 \%$ would be predicted, suggesting that mineral dust cannot be ruled out as the source of IN. Therefore, measurements are still needed to isolate the specific composition of IN within biomass burning plumes, as discussed by Twohy et al. (2010).

Across five wave cloud research flights during the ICE-L field campaign, Twohy et al. (2010) observed positive correlations between IN concentrations and the number concentrations of soot and biomass burning particle types. The IN concentrations measured within the smoke plumes differ from those predicted by the parameterization of DeMott et al. (2010) (Table 4), which is based a multi-project ambient air compilation and utilizes temperature and the fraction of particles $>0.5 \mu \mathrm{m}$. This is likely due to the fact that 
Table 4. CCN number concentrations are shown (with standard deviations), as well as the fraction of $\mathrm{CN}$ ( $>13 \mathrm{~nm}$ ) activating as CCN, at $0.5 \%$ supersaturation with respect to water; the average $\mathrm{CCN} / \mathrm{CN}$ value $>1$ is physically impossible and shows the uncertainty associated with the measurements and time synchronization. Measured IN number concentrations (with $95 \%$ confidence intervals) are shown for immersion/condensation freezing IN at the noted CFDC processing temperatures. IN/IN ${ }_{D 2010}$ described the measured IN number concentration divided by that predicted by the parameterization of DeMott et al. (2010). RF03 Periods 1-4 and the RF01 average correspond to approximate aerosol ages of $\sim 2-4 \mathrm{~min}, \sim 32-39 \mathrm{~min}, \sim 52-62 \mathrm{~min}, \sim 81-88 \mathrm{~min}$, and $\sim 17-30 \mathrm{~min}$, respectively.

\begin{tabular}{lccccc}
\hline & $\mathrm{CCN}_{0.5 \%}\left(\mathrm{~cm}^{-3}\right)$ & $\mathrm{CCN}_{0.5 \%} / \mathrm{CN}$ & CFDC Temp. $\left({ }^{\circ} \mathrm{C}\right)$ & $\mathrm{IN}\left(\mathrm{L}^{-1}\right)$ & $\mathrm{IN}_{\mathrm{IN}}$ 2010 \\
\hline RF03 Period 1 & $15318(2508)$ & $1.12(0.26)$ & -31.5 & $22(9)$ & $0.21(0.09)$ \\
RF03 Period 2 & $3005(73)$ & $0.59(0.03)$ & -31.7 & $16(8)$ & $0.11(0.05)$ \\
RF03 Period 3 & $1780(128)$ & $0.58(0.06)$ & -32.2 & $10(4)$ & $0.07(0.03)$ \\
RF03 Period 4 & $350(12)$ & $0.111(0.003)$ & -34.2 & $30(12)$ & $0.29(0.12)$ \\
RF01 Average & $852(86)$ & $0.28(0.02)$ & -33.5 & $47(9)$ & $2.9(0.6)$ \\
\hline
\end{tabular}

the compositions of $>500 \mathrm{~nm}$ particles in biomass burning plumes are representative of a specific source rather than the average ambient free troposphere (DeMott et al., 2010; Pratt and Prather, 2010).

\section{Conclusions}

As a major source of aerosols, biomass burning emissions significantly impact global direct radiative forcing and cloud properties (Forster et al., 2007). Given predicted increases in wildfires, particularly in the western United States (Westerling et al., 2006; Spracklen et al., 2009), it is important to understand the physical and chemical properties of biomass burning aerosols, as well as their links to optical and cloud properties (Reid et al., 2005b). Prescribed fires provide the opportunity for a detailed characterization of both burn conditions and consequent emissions in a realworld setting, combining the advantages of studying wildfires and laboratory fires. During ICE-L, the smoke plumes of two Wyoming BLM prescribed burns were intercepted aboard the NCAR/NSF C-130 aircraft. While most airborne plume studies have focused on large fires (e.g. Capes et al., 2008; Yokelson et al., 2009), this study examined two relatively small prescribed burns, characterized primarily by live mountain big sagebrush combustion, with particle aging examined in detail. The chemical composition of the biomass burning particles was investigated in detail utilizing a unique suite of real-time aerosol instrumentation, measuring sizeresolved single-particle chemical composition, size-resolved non-refractory mass concentrations, and black carbon mass concentrations. For one plume, the chemical composition was monitored in real-time for smoke particle aging from $\sim 2$ min to $\sim 2 \mathrm{~h}$. This work contributes to understanding the chemical composition and mixing state of biomass burning aerosols during aging from emission, using high time resolution measurements to bridge the gap between fresh and aged smoke particles, highlighted in a review by Reid et al. (2005b) as being a major need.
After $\sim 2-4$ min of aging, the fresh biomass burning particles were primarily internal mixtures of organic carbon, elemental carbon, potassium chloride, and potassium sulfate. The submicron smoke particles consisted primarily of organics by mass, with an increased fraction of oxidized organics with aging, coincident with the increased presence of dicarboxylic acids. Significantly, nitrate and sulfate were internally mixed with $100 \%$ of the fresh biomass burning particles, despite minor mass fractions, showing hygroscopic material present from the point of emission. Few fresh biomass burning particles by number were internally mixed with ammonium, consistent with the low ammonium mass fraction. Excess black carbon mass concentrations were correlated throughout the plumes with excess $\mathrm{CO}$ concentrations consistent with dilution. The mass fractions of ammonium, sulfate, and nitrate increased with aging and resulted in acidic particles, with both nitric acid and sulfuric acid present. Future work should focus on characterizing the partitioning and oxidation of organics during plume aging and dilution. $\mathrm{CCN}$ measurements at $0.5 \%$ supersaturation with respect to water suggested activation of all particles $>100 \mathrm{~nm}$ throughout the smoke plumes, confirming the high CCN activity of these freshly emitted particles. For immersion/condensation freezing, IN measurements at $-32{ }^{\circ} \mathrm{C}$ suggested activation of $\sim 0.03-0.07 \%$ of particles $>500 \mathrm{~nm}$. Mineral dust may be the source of the measured IN concentrations; however, future laboratory and ambient measurements are needed to specifically target and fully characterize the specific smoke plume particles acting as IN, since wildfires can be a significant source of IN (Petters et al., 2009b; Twohy et al., 2010).

Acknowledgements. Jay Esperance, Kristi Bulock, and Aaron Mier at the Wyoming Bureau of Land Management are thanked for prescribed burn ground-based data. NSF and NCAR are acknowledged for financial support of the ICE-L field campaign, as well as the work of T. Campos, D. C. Rogers, and A. J. Heymsfield. K. A. Pratt and K. A. Prather acknowledge NSF for support of ICE-L (ATM-0650659), A-ATOFMS development (ATM0321362), and a graduate research fellowship for K. A. Pratt. 
S. M. Murphy and J. H. Seinfeld acknowledge NSF for support of ICE-L (ATM-0340832) and NASA for an Earth and Space Sciences Fellowship for S. M. Murphy. R. Subramanian and G. L. Kok acknowledge NSF for ICE-L support (ATM-0631919). P. J. DeMott and A. J. Prenni acknowledge support from NSF (ATM-0611936). K. A. Pratt and S. M. Murphy also acknowledge a NOAA Climate \& Global Change Postdoctoral Fellowship and a National Research Council Postdoctoral Fellowship, respectively. Daniel Cziczo (Pacific Northwest National Laboratory) is thanked for discussions.

Edited by: O. Möhler

\section{References}

Aiken, A. C., DeCarlo, P. F., Kroll, J. H., Worsnop, D. R., Huffman, J. A., Docherty, K. S., Ulbrich, I. M., Mohr, C., Kimmel, J. R., Sueper, D., Sun, Y., Zhang, Q., Trimborn, A., Northway, M., Ziemann, P. J., Canagaratna, M. R., Onasch, T. B., Alfarra, M. R., Prévôt, A. S. H., Dommen, J., Duplissy, J., Metzger, A., Baltensperger, U., and Jimenez, J. L.: O/C and OM/OC ratios of primary, secondary, and ambient organic aerosols with high-resolution time-of-flight aerosol mass spectrometry, Environ. Sci. Technol., 42, 4478-4485, 2008.

Alfarra, M. R., Prevot, A. S. H., Szidat, S., Sandradewi, J., Weimer, S., Lanz, V. A., Schreiber, D., Mohr, M., and Baltensperger, U.: Identification of the mass spectral signature of organic aerosols from wood burning emissions, Environ. Sci. Technol., 41, 57705777, 2007.

Andreae, M. O. and Rosenfeld, D.: Aerosol-cloud-precipitation interactions. Part 1. The nature and sources of cloud-active aerosols, Earth-Sci. Rev., 89, 13-41, 2008.

Bahreini, R., Dunlea, E. J., Matthew, B. M., Simons, C., Docherty, K. S., DeCarlo, P. F., Jimenez, J. L., Brock, C. A., and Middlebrook, A. M.: Design and operation of a pressure-controlled inlet for airborne sampling with an aerodynamic aerosol lens, Aerosol Sci. Technol., 42, 465-471, 2008.

Baumgardner, D., Kok, G. L., and Raga, G. B.: On the diurnal variability of particle properties related to light absorbing carbon in Mexico City, Atmos. Chem. Phys., 7, 2517-2526, 2007, http://www.atmos-chem-phys.net/7/2517/2007/.

Baumgardner, D., Subramanian, R., Twohy, C., Stith, J., and Kok, G.: Scavenging of black carbon by ice crystals over the northern Pacific, Geophys. Res. Lett., 35, L22815, doi:10.1029/2008GL035764, 2008.

Bhave, P. V., Allen, J. O., Morrical, B. D., Fergenson, D. P., Cass, G. R., and Prather, K. A.: A field-based approach for determining ATOFMS instrument sensitivities to ammonium and nitrate, Environ. Sci. Technol., 36, 4868-4879, 2002.

Cahill, C. F., Cahill, T. A., and Perry, K. D.: The size- and timeresolved composition of aerosols from a sub-Arctic boreal forest prescribed burn, Atmos. Environ., 42, 7553-7559, 2008.

Capes, G., Johnson, B., McFiggans, G., Williams, P. I., Haywood, J., and Coe, H.: Aging of biomass burning aerosols over West Africa: Aircraft measurements of chemical composition, microphysical properties, and emission ratios, J. Geophys. Res., 113, D00C15, doi:10.1029/2008JD009845, 2008.

Carrico, C. M., Petters, M. D., Kreidenweis, S. M., Sullivan, A. P., McMeeking, G. R., Levin, E. J. T., Engling, G., Malm, W. C., and
Collett, J. L.: Water uptake and chemical composition of fresh aerosols generated in open burning of biomass, Atmos. Chem. Phys., 10, 5165-5178, doi:10.5194/acp-10-5165-2010, 2010.

Chand, D., Wood, R., Anderson, T. L., Satheesh, S. K., and Charlson, R. J.: Satellite-derived direct radiative effect of aerosols dependent on cloud cover, Nature Geosci., 2, 181-184, 2009.

Chen, L.-W. A., Moosmüller, H., Arnott, W. P., Chow, J. C., Watson, J. G., Susott, R. A., Babbitt, R. E., Wold, C. E., Lincoln, E. N., and Hao, W. M.: Emissions from laboratory combustion of wildland fuels: Emission factors and source profiles, Environ. Sci. Technol., 41, 4317-4325, 2007.

Clarke, A., McNaughton, C., Kapustin, V., Shinozuka, Y., Howell, S., Dibb, J., Zhou, J., Anderson, B., Brekhovskikh, V., Turner, H., and Pinkerton, M.: Biomass burning and pollution aerosol over North America: Organic components and their influence on spectral optical properties and humidification response, J. Geophys. Res., 112, D12S18, doi:10.1029/2006JD007777, 2007.

Crutzen, P. J., Lawrence, M. G., and Pöschl, U.: On the background photochemistry of tropospheric ozone, Tellus, 51A-B, 123-146, 1999.

DeCarlo, P. F., Dunlea, E. J., Kimmel, J. R., Aiken, A. C., Sueper, D., Crounse, J., Wennberg, P. O., Emmons, L., Shinozuka, Y., Clarke, A., Zhou, J., Tomlinson, J., Collins, D. R., Knapp, D., Weinheimer, A. J., Montzka, D. D., Campos, T., and Jimenez, J. L.: Fast airborne aerosol size and chemistry measurements above Mexico City and Central Mexico during the MILAGRO campaign, Atmos. Chem. Phys., 8, 4027-4048, doi:10.5194/acp8-4027-2008, 2008.

DeMott, P. J., Prenni, A. J., Liu, X., Kreidenweis, S. M., Petters, M. D., Twohy, C. H., Richardson, M. S., Eidhammer, T., and Rogers, D. C.: Predicting global atmospheric ice nuclei distributions and their impacts on climate, Proc. Natl. Acad. Sci. USA, 107, 11217-11222, 2010.

Denkenberger, K. A., Moffet, R. C., Holecek, J. C., Rebotier, T. P., and Prather, K. A.: Real-time, single-particle measurements of oligomers in aged ambient aerosol particles, Environ. Sci. Technol., 41, 5439-5446, 2007.

Donahue, N. M., Robinson, A. L., Stanier, C. O., and Pandis, S. N.: Coupled partitioning, dilution, and chemical aging of semivolatile organics, Environ. Sci. Technol., 40, 2635-2643, 2006.

Drewnick, F., Hings, S. S., DeCarlo, P., Jayne, J. T., Gonin, M., Fuhrer, K., Weimer, S., Jimenez, J. L., Demerjian, K. L., Borrmann, S., and Worsnop, D. R.: A new time-of-flight aerosol mass spectrometer (TOF-AMS) - Instrument description and first field deployment, Aerosol Sci. Technol., 39, 637-658, 2005.

Eagan, R. C., Hobbs, P. V., and Radke, L. F.: Measurements of cloud condensation nuclei and cloud droplet size distributions in the vicinity of forest fires, J. Appl. Meteorol., 13, 553-557, 1974.

Eidhammer, T., DeMott, P. J., Prenni, A. J., Petters, M. D., Twohy, C. H., Rogers, D. C., Stith, J., Heymsfield, A., Wang, Z., Pratt, K A., Prather, K. A., Murphy, S. M., Seinfeld, J. H., Subramanian, R., and Kreidenweis, S. M.: Ice initiation by aerosol particles: Measured and predicted ice nuclei concentrations versus measured ice crystal concentrations in an orographic wave cloud, J. Atmos. Sci., 67, 2417-2436, 2010.

Field, P. R., Mohler, O., Connolly, P., Kramer, M., Cotton, R., Heymsfield, A. J., Saathoff, H., and Schnaiter, M.: Some ice nucleation characteristics of Asian and Saharan desert dust, At- 
mos. Chem. Phys., 6, 2991-3006, doi:10.5194/acp-6-2991-2006, 2006.

Forster, P., Ramaswamy, V., Artaxo, P., Berntsen, T., Betts, R., Fahey, D. W., Haywood, J., Lean, J., Lowe, D. C., Myhre, G., Nganga, J., Prinn, R., Raga, G., Schulz, M., and Van Dorland, R.: Changes in Atmospheric Constituents and in Radiative Forcing, in: Climate Change 2007: The Physical Science Basis. Contribution of Working Group I to the Fourth Assessment Report of the Intergovernmental Panel on Climate Change, edited by: Solomon, S., Qin, D., Manning, M., Chen, Z., Marquis, M., Averyt, K. B., Tignor, M., and Miller, H. L., Cambridge University Press, New York, NY, 129-234, 2007.

Gao, S., Hegg, D. A., Hobbs, P. V., Kirchstetter, T. W., Magi, B. I., and Sadilek, M.: Water-soluble organic components in aerosols associated with savanna fires in southern Africa: Identification, evolution, and distribution, J. Geophys. Res., 108, 8491, doi:10.1029/2002JD002324, 2003.

Gaudichet, A., Echalar, F., Chatenet, B., Quisefit, J. P., Malingre, G., Cachier, H., Buat-Menard, P., Artaxo, P., and Maenhaut, W.: Trace elements in tropical African savanna biomass burning aerosols, J. Atmos. Chem., 22, 19-39, 1995.

Goode, J. G., Yokelson, R. J., Ward, D. E., Susott, R. A., Babbitt, R. E., Davies, M. A., and Hao, W. M.: Measurements of excess $\mathrm{O}_{3}, \mathrm{CO}_{2}, \mathrm{CO}, \mathrm{CH}_{4}, \mathrm{C}_{2} \mathrm{H}_{4}, \mathrm{C}_{2} \mathrm{H}_{2}, \mathrm{HCN}, \mathrm{NO}, \mathrm{NH}_{3}$, $\mathrm{HCOOH}, \mathrm{CH}_{3} \mathrm{COOH}, \mathrm{HCHO}$, and $\mathrm{CH}_{3} \mathrm{OH}$ in 1997 Alaskan biomass burning plumes by airborne Fourier transform infrared spectroscopy (AFTIR), J. Geophys. Res., 105, 22147-22166, 2000.

Grieshop, A. P., Donahue, N. M., and Robinson, A. L.: Laboratory investigation of photochemical oxidation of organic aerosol from wood fires 2: analysis of aerosol mass spectrometer data, Atmos. Chem. Phys., 9, 2227-2240, doi:10.5194/acp-9-2227-2009, 2009.

Guyon, P., Frank, G. P., Welling, M., Chand, D., Artaxo, P., Rizzo, L., Nishioka, G., Kolle, O., Fritsch, H., Silva Dias, M. A. F., Gatti, L. V., Cordova, A. M., and Andreae, M. O.: Airborne measurements of trace gas and aerosol particle emissions from biomass burning in Amazonia, Atmos. Chem. Phys., 5, 29893002, doi:10.5194/acp-5-2989-2005, 2005.

Hawkins, L. N. and Russell, L. M.: Oxidation of ketone groups in transported biomass burning aerosol from the 2008 Northern California Lightning Series fires, Atmos. Environ., 44, 41424154, 2010.

Heald, C. L., Kroll, J. H., Jimenez, J. L., Docherty, K. S., DeCarlo, P. F., Aiken, A. C., Chen, Q., Martin, S. T., Farmer, D. K., and Artaxo, P.: A simplified description of the evolution of organic aerosol composition in the atmosphere, Geophys. Res. Lett., 37, L08803, doi:10.1029/2010GL042737, 2010.

Hennigan, C. J., Sullivan, A. P., Collett, J. L., and Robinson, A. L.: Levoglucosan stability in biomass burning particles exposed to hydroxyl radicals, Geophys. Res. Lett., 37, L09806, doi:10.1029/2010GL043088, 2010.

Hennigan, C. J., Miracolo, M. A., Engelhart, G. J., May, A. A., Presto, A. A., Lee, T., Sullivan, A. P., McMeeking, G. R., Coe, H., Wold, C. E., Hao, W.-M., Gilman, J. B., Kuster, W. C., de Gouw, J., Schichtel, B. A., Collett, J. L., Kreidenweis, S. M., and Robinson, A. L.: Chemical and physical transformations of organic aerosol from the photo-oxidation of open biomass burning emissions in an environmental chamber, Atmos. Chem. Phys.,
11, 7669-7686, doi:10.5194/acp-11-7669-2011, 2011.

Hobbs, P. V. and Locatelli, J. D.: Ice nuclei from a natural forest fire, J. Appl. Meteorol., 8, 833-834, 1969.

Hobbs, P. V. and Radke, L. F.: Cloud condensation nuclei from a simulated forest fire, Science, 163, 279-280, 1969.

Hobbs, P. V., Sinha, P., Yokelson, R. J., Christian, T. J., Blake, D. R., Gao, S., Kirchstetter, T. W., Novakov, T., and Pilewskie, P.: Evolution of gases and particles from a savanna fire in South Africa, J. Geophys. Res., 108, 8485, doi:10.1029/2002JD002352, 2003.

Hudson, P. K., Murphy, D. M., Cziczo, D. J., Thomson, D. S., de Gouw, J. A., Warneke, C., Holloway, J., Jost, J. R., and Hubler, G.: Biomass-burning particle measurements: Characteristic composition and chemical processing, J. Geophys. Res., 109, D23S27, doi:10.1029/2003JD004398, 2004.

Huffman, J. A., Jayne, J. T., Drewnick, F., Aiken, A. C., Onasch, T., Worsnop, D. R., and Jimenez, J. L.: Design, modeling, optimization, and experimental tests of a particle beam width probe for the Aerodyne aerosol mass spectrometer, Aerosol Sci. Technol., 39, 1143-1163, 2005.

Kessler, S. H., Smith, J. D., Che, D. L., Worsnop, D. R., Wilson, K. R., and Kroll, J. H.: Chemical sinks of organic aerosol: Kinetics and products of the heterogeneous oxidation of erythritol and levoglucosan, Environ. Sci. Technol., 44, 7005-7010, 2010.

Knudsen, J. N., Jensen, P. A., and Dam-Johansen, K.: Transformation and release to the gas phase of $\mathrm{Cl}, \mathrm{K}$, and $\mathrm{S}$ during combustion of annual biomass, Energy Fuels, 18, 1385-1399, 2004.

Kroll, J. H., Smith, J. D., Che, D. L., Kessler, S. H., Worsnop, D. R., and Wilson, K. R.: Measurement of fragmentation and functionalization pathways in the heterogeneous oxidation of oxidized organic aerosol, Phys. Chem. Chem. Phys., 11, 8005-8014, 2009.

Li, J., Posfai, M., Hobbs, P. V., and Buseck, P. R.: Individual aerosol particles from biomass burning in southern Africa: 2. Compositions and aging of inorganic particles, J. Geophys. Res., 108, 8484, doi:10.1029/2002JD002310, 2003.

Liu, X., Van Espen, P., Adams, F., Cafmeyer, J., and Maenhaut, W.: Biomass burning in Southern Africa: Individual particle characterization of atmospheric aerosols and Savanna fire samples, J. Atmos. Chem., 36, 135-155, 2000.

Matthew, B. M., Middlebrook, A. M., and Onasch, T. B.: Collection efficiencies in an Aerodyne aerosol mass spectrometer as a function of particle phase for laboratory generated aerosols, Aerosol Sci. Technol., 42, 884-898, 2008.

McMeeking, G. R., Kreidenweis, S. M., Baker, S., Carrico, C. M., Chow, J. C., Collett, J. L., Hao, W. M., Holden, A. S., Kirchstetter, T. W., Malm, W. C., Moosmüller, H., Sullivan, A. P., and Wold, C. E.: Emissions of trace gases and aerosols during the open combustion of biomass in the laboratory, J. Geophys. Res., 114, D19210, doi:10.1029/2009JD011836, 2009.

Möhler, O., DeMott, P. J., Vali, G., and Levin, Z.: Microbiology and atmospheric processes: the role of biological particles in cloud physics, Biogeosciences, 4, 1059-1071, doi:10.5194/bg-4-10592007, 2007.

Moteki, N. and Kondo, Y.: Effects of mixing state on black carbon measurements by laser-induced incandescence, Aerosol Sci. Technol., 41, 398-417, 2007.

Moteki, N., Kondo, Y., Miyazaki, Y., Takegawa, N., Komazaki, Y., Kurata, G., Shirai, T., Blake, D. R., Miyakawa, T., and Koike, M.: Evolution of mixing state of black carbon particles: Aircraft measurements over the western Pacific in March 2004, Geophys. 
Res. Lett., 34, L11803, doi:10.1029/2006GL028943, 2007.

Murphy, S. M., Agrawal, H., Sorooshian, A., Padró, L. T., Gates, H., Hersey, S., Welch, W. A., Jung, H., Miller, J. W., Cocker, D. R., Nenes, A., Jonsson, H. H., Flagan, R. C., and Seinfeld, J. H.: Comprehensive simultaneous shipboard and airborne characterization of exhuast from a modern container ship at sea, Environ. Sci. Technol., 43, 4626-4640, 2009.

Park, R. J., Jacob, D. J., and Logan, J. A.: Fire and biofuel contributions to annual mean aerosol mass concentrations in the United States, Atmos. Environ., 41, 7389-7400, 2007.

Petters, M. D., Carrico, C. M., Kreidenweis, S. M., Prenni, A. J., DeMott, P. J., Collett, J. L., and Moosmüller, H.: Cloud condensation nucleation activity of biomass burning aerosol, J. Geophys. Res., 114, D22205, doi:10.1029/2009JD012353, 2009a.

Petters, M. D., Parsons, M. T., Prenni, A. J., DeMott, P. J., Kreidenweis, S. M., Carrico, C. M., Sullivan, A. P., McMeeking, G. R., Levin, E., Wold, C. E., Collett, J. L., and Moosmuller, H.: Ice nuclei emissions from biomass burning, J. Geophys. Res., 114, D07209, doi:10.1029/2008JD011532, 2009b.

Pósfai, M., Simonics, R., Li, J., Hobbs, P. V., and Buseck, P. R.: Individual aerosol particles from biomass burning in southern Africa: 1. Compositions and size distributions of carbonaceous particles, J. Geophys. Res., 108, 8483, doi:10.1029/2002JD002291, 2003.

Pratt, K. A., Mayer, J. E., Holecek, J. C., Moffet, R. C., Sanchez, R. O., Rebotier, T. P., Furutani, H., Gonin, M., Fuhrer, K., Su, Y., Guazzotti, S., and Prather, K. A.: Development and characterization of an aircraft aerosol time-of-flight mass spectrometer, Anal. Chem., 81, 1792-1800, 2009.

Pratt, K. A. and Prather, K. A.: Aircraft measurements of vertical profiles of aerosol mixing states, J. Geophys. Res., 115, D11305, doi:10.1029/2009JD013150, 2010.

Prenni, A. J., Petters, M. D., Kreidenweis, S. M., Heald, C. L., Martin, S. T., Artaxo, P., Garland, R. M., Wollny, A. G., and Pöschl, U.: Relative roles of biogenic emissions and Saharan dust as ice nuclei in the Amazon basin, Nature Geosci., 2, 402-405, 2009.

Pueschel, R. F. and Langer, G.: Sugar cane fires as a source of ice nuclei in Hawaii, J. Appl. Meteorol., 12, 549-551, 1973.

Reid, J. S., Eck, T. F., Christopher, S. A., Koppmann, R., Dubovik, O., Eleuterio, D. P., Holben, B. N., Reid, E. A., and Zhang, J.: A review of biomass burning emissions part III: intensive optical properties of biomass burning particles, Atmos. Chem. Phys., 5, 827-849, doi:10.5194/acp-5-827-2005, 2005a.

Reid, J. S., Koppmann, R., Eck, T. F., and Eleuterio, D. P.: A review of biomass burning emissions part II: Intensive physical properties of biomass burning particles, Atmos. Chem. Phys., 5, 799825, doi:10.5194/acp-5-799-2005, 2005b.

Roberts, G. C. and Nenes, A.: A continuous-flow streamwise thermal-gradient $\mathrm{CCN}$ chamber for atmospheric measurements, Aerosol Sci. Technol., 39, 206-221, 2005.

Rogers, D. C., DeMott, P. J., Kreidenweis, S. M., and Chen, Y.: A continuous-flow diffusion chamber for airborne measurements of ice nuclei, J. Atmos. Ocean. Technol., 18, 725-741, 2001.

Schneider, J., Weimer, S., Drewnick, F., Borrmann, S., Helas, G., Gwaze, P., Schmid, O., Andreae, M. O., and Kirchner, U.: Mass spectrometric analysis and aerodynamic properties of various types of combustion-related aerosol particles, Int. J. Mass Spectrom., 258, 37-49, 2006.

Schwarz, J. P., Gao, R. S., Fahey, D. W., Thomson, D. S., Watts,
L. A., Wilson, J. C., Reeves, J. M., Darbeheshti, M., Baumgardner, D. G., Kok, G. L., Chung, S. H., Schulz, M., Hendricks, J., Lauer, A., Kärcher, B., Slowik, J. G., Rosenlof, K. H., Thompson, T. L., Langford, A. O., Loewenstein, M., and Aikin, K. C.: Single-particle measurements of midlatitude black carbon and light-scattering aerosols from the boundary layer to the lower stratosphere, J. Geophys. Res., 111, D16207, doi:10.1029/2006JD007076, 2006.

Silva, P. J., Liu, D. Y., Noble, C. A., and Prather, K. A.: Size and chemical characterization of individual particles resulting from biomass burning of local Southern California species, Environ. Sci. Technol., 33, 3068-3076, 1999.

Simoneit, B. R. T., Schauer, J. J., Nolte, C. G., Oros, D. R., Elias, V. O., Fraser, M. P., Rogge, W. F., and Cass, G. R.: Levoglucosan, a tracer for cellulose in biomass burning and atmospheric particles, Atmos. Environ., 33, 173-182, 1999.

Spencer, M. T., and Prather, K. A.: Using ATOFMS to determine OC/EC mass fractions in particles, Aerosol Sci. Technol., 40, 585-594, 2006.

Spracklen, D. V., Mickley, L. J., Logan, J. A., Hudman, R. C. Yevich, R., Flannigan, M. D., and Westerling, A. L.: Impacts of climate change from 2000 to 2050 on wildfire activity and carbonaceous aerosol concentrations in the western United States, J. Geophys. Res., 114, D20301, doi:10.1029/2008JD010966, 2009.

Stith, J. L., Radke, L. F., and Hobbs, P. V.: Particle emissions and the production of ozone and nitrogen oxides from the burning of forest slash, Atmos. Environ., 15, 73-82, 1981.

Stith, J. L., Twohy, C. H., DeMott, P. J., Baumgardner, D., Campos, T., Gao, R., and Anderson, J.: Observations of ice nuclei and heterogeneous freezing in a Western Pacific extratropical storm, Atmos. Chem. Phys., 11, 6229-6243, doi:10.5194/acp-11-62292011, 2011.

Subramanian, R., Roden, C. A., Boparai, P., and Bond, T. C.: Yellow beads and missing particles: Trouble ahead for filter-based absorption measurements, Aerosol Sci. Technol., 41, 630-637, 2007.

Subramanian, R., Kok, G. L., Baumgardner, D., Clarke, A., Shinozuka, Y., Campos, T. L., Heizer, C. G., Stephens, B. B., de Foy, B., Voss, P. B., and Zaveri, R. A.: Black carbon over Mexico: the effect of atmospheric transport on mixing state, mass absorption cross-section, and BC/CO ratios, Atmos. Chem. Phys., 10, 219-237, doi:10.5194/acp-10-219-2010, 2010.

Sullivan, A. P., Holden, A. S., Patterson, L. A., McMeeking, G R., Kreidenweis, S. M., Malm, W. C., Hao, W. M., Wold, C. E., and Collett, J. L.: A method for smoke marker measurements and its potential application for determining the contribution of biomass burning from wildfires and prescribed fires to ambient $\mathrm{PM}_{2.5}$ organic carbon, J. Geophys. Res., 113, D22302, doi:10.1029/2008JD010216, 2008.

Sullivan, R. C. and Prather, K. A.: Investigations of the diurnal cycle and mixing state of oxalic acid in individual particles in Asian aerosol outflow, Environ. Sci. Technol., 41, 8062-8069, 2007.

Twohy, C. H., DeMott, P. J., Pratt, K. A., Subramanian, R., Kok, G. L., Murphy, S. M., Lersch, T., Prather, K. A., Seinfeld, J. H., Heymsfield, A. J., and Wang, Z.: Relationships of biomass burning aerosols to ice in orographic wave clouds, J. Atmos. Sci., 67, 2437-2450, 2010.

Weimer, S., Alfarra, M. R., Schreiber, D., Mohr, M., Prévôt, A. S. H., and Baltensperger, U.: Organic aerosol mass spectral 
signatures from wood-burning emissions: Influence of burning conditions and wood type, J. Geophys. Res., 113, D10304, doi:10.1029/2007JD009309, 2008.

Westerling, A. L., Hidalgo, H. G., Cayan, D. R., and Swetnam, T. W.: Warming and earlier spring increase western U.S. forest wildfire activity, Science, 313, 940-943, 2006.

Wiedinmyer, C. and Hurteau, M. D.: Prescribed fire as a means of reducing forest carbon emissions in the western United States, Environ. Sci. Technol., 44, 1926-1932, 2010.

Yao, X., Rehbein, P. J. G., Lee, C. J., Evans, G. J., Corbin, J., and Jeong, C.-H.: A study on the extent of neutralization of sulphate aerosol through laboratory and field experiments using an ATOFMS and a GPIC, Atmos. Environ., 45, 6251-6256, 2011.
Yokelson, R. J., Crounse, J. D., DeCarlo, P. F., Karl, T., Urbanski, S., Atlas, E., Campos, T., Shinozuka, Y., Kapustin, V., Clarke, A. D., Weinheimer, A., Knapp, D. J., Montzka, D. D., Holloway, J., Weibring, P., Flocke, F., Zheng, W., Toohey, D., Wennberg, P. O., Wiedinmyer, C., Mauldin, L., Fried, A., Richter, D., Walega, J., Jimenez, J. L., Adachi, K., Buseck, P. R., Hall, S. R., and Shetter, R.: Emissions from biomass burning in the Yucatan, Atmos. Chem. Phys., 9, 5785-5812, doi:10.5194/acp-9-5785-2009, 2009.

Zhang, Q., Jimenez, J. L., Worsnop, D. R., and Canagaratna, M.: A case study of urban particle acidity and its influence on secondary organic aerosol, Environ. Sci. Technol., 41, 3213-3219, 2007. 